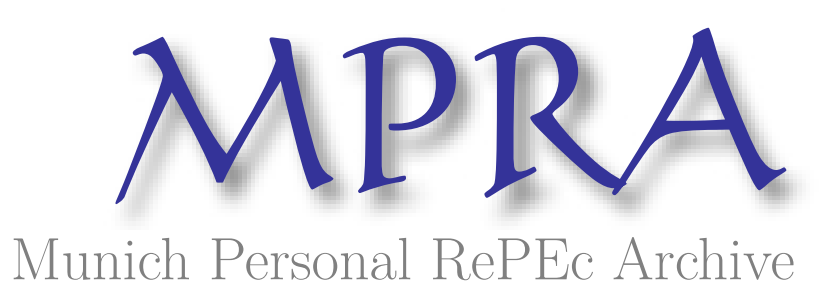

\title{
Understanding Financial Instability: Minsky Versus the Austrians
}

Van den Hauwe, Ludwig

Independent Researcher

24 December 2014

Online at https://mpra.ub.uni-muenchen.de/60718/

MPRA Paper No. 60718, posted 26 Dec 2014 16:21 UTC 


\section{Understanding Financial Instability: Minsky versus the Austrians}

\section{By Ludwig van den Hauwe, Ph.D.}

\section{Financial Crisis, Great Recession and Heterodox Macroeconomics}

There is a widespread perception that the fact that mainstream economics proved useless in predicting, tackling or even imagining the biggest financial debacle in the world's most advanced economies for eighty years constitutes clear evidence of its intellectual failure. (Kates 2010, 2011; Wolf 2014)

One heterodox approach that has gained enormous influence and prestige among interpreters of the financial and economic crisis that began in 2007-8 is that of the late Hyman Minsky. Minsky's view was that economics should include the possibility of severe crises, not as the result of external shocks, but as events that emerge from within the system. Crises, according to Minsky, have proved a persistent feature of capitalist economies. Minsky's financial instability hypothesis is a model of a capitalist economy which does not rely upon exogenous shocks to generate business cycles of varying severity: the hypothesis contends that historical business cycles are compounded out of the internal dynamics of capitalist economies as well as out of the system of interventions and regulations designed to keep the economy operating within reasonable bounds.

As the author of one such influential narrative conceded recently: 
"My personal perspective on economics has failed the test set by the late and almost universally ignored Hyman Minsky. (...) This book aims to learn from that mistake. One of its goals is to ask whether Minsky's demand for a theory that generates the possibility of great depressions is reasonable and, if so, how economists should respond. I believe it is quite reasonable." (Wolf 2014, xvi)

Wolf also raises the following question:

"Were the Austrian economists or the post-Keynesians closer to the truth than orthodox economists who ran central banks and advised treasuries? The answer will be that the heterodox economists were indeed more right than the orthodox.” (ibid. 5)

This observation still leaves open the answer to the question of whether the Austrian or the post-Keynesian economists were actually right. It would be highly misleading to suggest that both heterodox approaches, the Austrian and the Minskyan, offer somehow similar analyses of what went wrong, or that they offer similar advice as to the appropriate remedies. Somewhat less influential but no less relevant and pertinent has indeed been the approach of economists of the Austrian School in explaining and understanding the events leading up to the financial crises and the following economic recession. It has not always been clearly perceived, however, whether the post-Keynesian and Austrian accounts are complementary, partly complementary and partly incompatible, or entirely incompatible. Roughly speaking, and as Wolf himself points out, the issue can be summarized as follows: Despite their differences, the post-Keynesian school, with its suspicion of free markets, and the Austrian school, with its fervent belief in them, both agree that crises are inevitable in our present economic system, though they disagree on what causes crisis and what to do about them when they happen. (Wolf 2014, xvii) 
Leijonhufvud $(2009,742)$, however, suggests complementarity rather than incompatibility between the two approaches. Writing about the financial crisis, he writes:

"Operating an interest targeting regime keying on the consumer price index (CPI), the Fed was lured into keeping interest rates far too low for far too long. The result was inflation of asset prices combined with a general deterioration of credit quality (....). This, of course, does not make a Keynesian story. Rather, it is a variation on the Austrian overinvestment (or malinvestment) theme. But Mises and Hayek had very little to say about the financial side of an overinvestment boom that is of interest to us 80 years later. For a thorough analysis of that subject one has to turn to Human Minsky."

Resolving this issue in greater detail, however, requires taking a closer look at the specifics of the respective theories. This is the purpose of this paper.

I will first summarize Minsky's FIH as well as the Austrian theory of the business cycle. Subsequently I will proceed to a discussion comparing both approaches along several dimensions. I will also mention some contributions within both schools offering analyses of the historical experience of the Financial Crisis and Great Recession. Finally, I will discuss the policy implications according to both theories.

This investigation will allow us to conclude that whatever similarities or even analogies may exist between both approaches these are in fact highly superficial while at a fundamental conceptual level the divergences between the two approaches remain profound and fundamental. 


\section{The Austrian theory of the business cycle in a nutshell}

As explained by Garrison $(2001,2005)$ the Austrian theory of the business cycle emerges from a straightforward comparison of savings-induced growth which is sustainable, with a credit-induced boom, which is not sustainable.

An increase in saving by individuals and a credit expansion orchestrated by the central bank set into motion market processes whose initial allocational effects on the economy's capital structure are similar. The ultimate consequences of the two processes stand in stark contrast, however. Whereas saving entails genuine growth, credit expansion leads to boom and bust. If market participants' time preferences, i.e. their degree of preference for present over future goods, falls, then they will tend to consume less now and save and invest more; at the same time, and for the same reason, the rate of interest will fall. A decrease in the interest rate causes resources to be transferred from the late and final stages to the early stages. The structure of production is thus modified. It will now be depicted by a Hayekian triangle with a longer time-dimension leg and an (initially) shorter consumable-output leg. The time profile of consumption thus becomes skewed toward the future. In a genuine savings-induced boom increased investment in longer-term projects is thus consistent with the underlying economic realities. This is not true in the case of a policy-induced artificial boom. In the hypothesis of an artificial boom, the change in the interest-rate signal and the change in resource availabilities are at odds with one another. If the central bank pads the supply of loanable funds with newly created money, the interest rate is lowered and long-term investment projects are being initiated, just as in the case of an increase in saving. However, in the absence of an actual change in time preferences, no additional resources for sustaining the policy-induced boom are freed up. In fact, facing a lower interest rate, people will save less and spend more on current consumables. In other words, the 
central bank's credit expansion drives a wedge between saving and investment; it results in an incompatible mix of market forces. Malinvestment and overconsumption will be observed. Of course, as the market guides these new long-term investment projects into their intermediate and later stages, the underlying economic realities become increasingly clear and ultimately reaffirm themselves. Entrepreneurs will encounter resource scarcities that are more constraining than was implied by the pattern of wages, prices, and interest rates that characterized the early phase of the boom. The bidding for increasingly scarce resources and the accompanying increased demands for credit put upward pressure on the interest rate. On the eve of the bust, "distress borrowing" allows some producers to finish their projects and minimize their losses. At the same time, the high interest rates cause people to curtail their consumption and to save instead. Where "overconsumption" had first been observed, "forced saving" now takes place. The change in saving is far short of sufficient, however, in comparison to the saving actually needed to see the policy-induced investments through to completion. The ensuing period of liquidation involves higher-than-normal levels of unemployment.

Clearly the consumption and investment magnitudes will not simply return to their previous pre-boom sustainable levels. Given the intertemporal disequilibrium created during the boom, needed liquidation may well take the economy inside its production possibilities frontier (PPF). Under favourable conditions, market forces may bring business decisions back into conformity with actual consumer preferences.

There is clearly also a danger, however, especially in the face of ill-conceived policy actions by the monetary and fiscal authorities, that the recovery phase will be preempted by spiraling downward into deep depression, that is, selfreversing changes in the capital structure may give way to a self-aggravating downward spiral in both income and spending. 
The market is capable of allocating resources in conformity with intertemporal preferences on the basis of a market-determined (natural) rate of interest. It follows, then, almost as a corollary that an interest rate substantially influenced by extra-market forces will lead to an intertemporal misallocation of resources.

The role of the central bank and the consequences of its liquidity-providing interventions are illustrated in Figure 1.

Figure 1

C

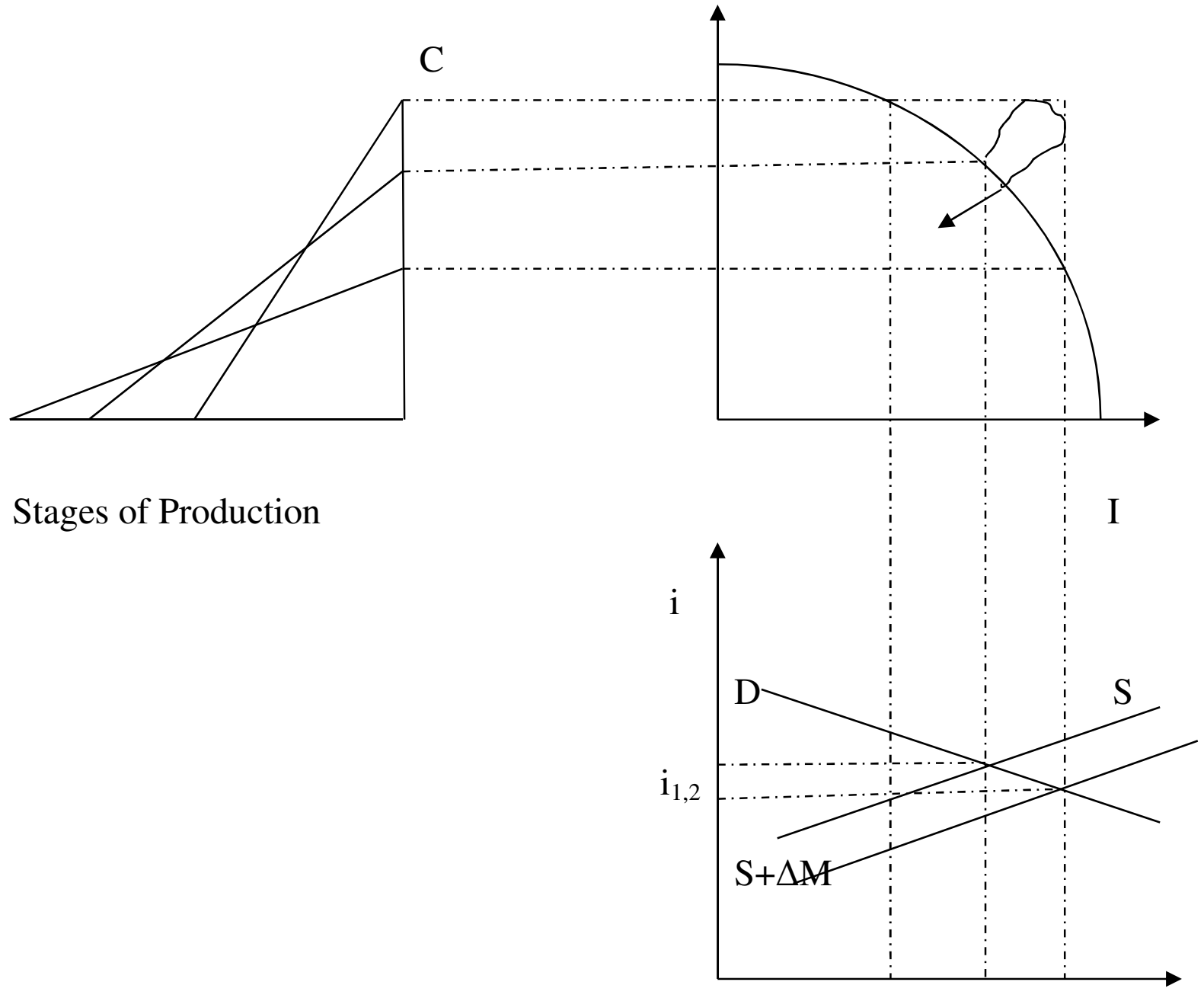

$\mathrm{S}_{2} \quad \mathrm{~S}_{1=} \mathrm{I}_{1} \quad \mathrm{I}_{2} \quad \mathrm{~S} / \mathrm{I}$

A lowering of the interest rate from $i_{1}$ to $i_{2}$ drives a wedge between saving and investment. The supply and demand of loanable funds are in equilibrium, 
$\mathrm{I}_{2}=\mathrm{S}_{2}+\Delta \mathrm{M}$, but there is no equilibrium between saving and investment $\left(\mathrm{S}_{2}<\mathrm{I}_{2}\right)$. The wedge between saving and investment shown in the loanable funds market translates to the production possibilities frontier (PPF) as a tug-of-war between consumers and investors. The conflicting market forces that are trying to pull the economy in opposite directions are manifested in the economy's capital structure as clashing triangles. (also Gloria-Palermo 2013, 86-87; Van den Hauwe 2009, 13-14)

The Austrian theory of the business cycle is thus a theory of boom and bust with special attention to the extra-market forces that initiate the boom and the market's own self-correcting forces that turn boom into bust. Whereas increased saving lowers the rate of interest and gives rise to a genuine boom-one in which no self-correction is called for; the economy now simply grows at a more rapid rate-by contrast, a falsified interest rate that mimics the loan market conditions of a genuine boom but is not accompanied by the requisite savings gives rise to an artificial boom, one whose artificiality is eventually revealed by the market's reaction to excessively future-oriented production activities in conditions of insufficient saving. Misallocations are followed by reallocations.

The Austrian theory is not a theory of depression per se but rather a theory of the unsustainable boom. The focus of the theory is the intertemporal discoordination-a general mismatch between intertemporal consumption and saving preferences and intertemporal production plans-and hence the inevitable crisis and downturn. (Garrison ibid. 240) As pointed out already, Austrians recognize that self-reversing changes in the capital structure may give way to a self-aggravating downward spiral in both income and spending. The spiraling downward, which was the primary focus of conventionally interpreted Keynesianism, was described by Hayek as the "secondary deflation"-in recognition of the fact that the primary problem was something else: the intertemporal misallocation of resources, or, to use Mises's term, 
malinvestment. (ibid. 75) Austrians thus acknowledge the fact that a bad situation can get worse but would generally argue that the self-aggravating downward spiral leading into deep depression is to be explained by significant government intervention on several levels thwarting market adjustment by constraining exchange opportunities.

\section{Minsky's Financial Instability Hypothesis in a nutshell}

In this section I will provide a summary statement of Minsky's analysis of financial instability. The post-Keynesian literature contains several excellent summaries which I will use freely, besides Minsky's three books. (Bellofiore and Ferri 2001a and 2001b; Fazzari and Papadimitriou 1992; Papadimitriou and Wray 2010; De Antoni 2010)

The two cornerstones of Minsky's analysis are his "financial theory of investment" which considers the ways in which investment is financed, and the cumulative processes. (De Antoni ibid. 462)

The core of Minsky's analysis is a financial theory of investment according to which investment is essentially driven by: (i) the difference between the market price of capital goods in place and the current price of investments goods; (ii) the volume of internal finance.

As to the first factor, Minsky writes: "Prices of capital assets depend upon current views of future profit (quasi-rent) flows and the current subjective value placed upon the insurance against uncertainty embodied in money or quick cash: these current views depend upon expectations that are held about the longer run development of the economy. The prices of current output are based upon current views of near term demand conditions and current knowledge of money 
wage rates. Thus the prices of current output (...) depend upon shorter run expectations. Capital-asset and current output prices are based upon expectations over quite different time horizons: capital output prices reflect long run expectations and current output prices reflect short term expectations." (Minsky $1982,94-5)$

As to the second factor, Minsky notes that the investment which can be debt financed today depends on the cash flows expected by both borrowers (firms) and lenders (banks) tomorrow. The higher the realized cash flow relative to debt commitments, the higher the rate of fulfillment of contracts, which positively affects the state of confidence of both bankers and business people and leads to a higher volume of investment being financed and carried out.

Minsky's theory of investment determination can be illustrated with the help of Figure 2.

Figure 2

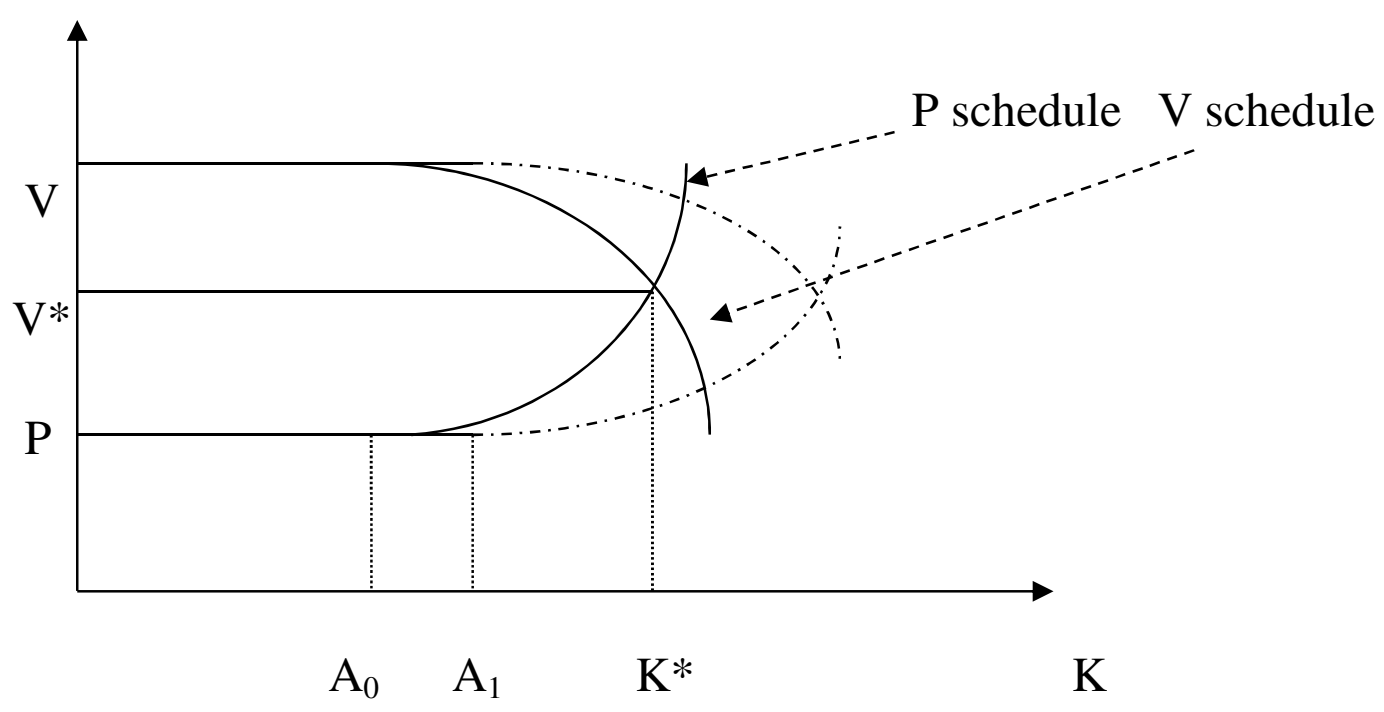


The quantity of capital is measured on the x-axis and the "prices" of capital on the $y$-axis. Minsky draws a distinction between the supply price of investment goods-which we assume for simplicity to be equal to the average price level (P) - and the market price of capital assets (V), which can be thought of as the present value of the stream of expected quasi rent per unit of capital. By assumption the latter coincides with the stock price.

Investment can be financed in part by means of internally generated funds, which coincide with net worth (A) and in part by external finance. For a given price of newly produced capital goods (say $\mathrm{P}_{0}$ ) and a given level of internal finance ( say $\mathrm{A}_{0}$ ) we can determine the maximum volume of investment which can be financed by means of internal funds $\mathrm{K}_{0}=\mathrm{A}_{0}$.

By assumption, the quasi rent is increasing with the volume of net worth. Hence we can compute the market price $\mathrm{V}_{0}$ as an increasing function of $\mathrm{A}_{0}$. (Assenza et al. 2010, 185)

If the firm chooses a level of investment greater than $\mathrm{K}_{0}$, it has to raise funds on the credit market. In this case banks have to be remunerated for the risk they assume (lender's risk), so that the actual supply price of investment goods for the borrowing firm is higher than the price of newly produced capital goods $\mathrm{P}_{0}$. The schedule of the actual price of investment goods (P schedule), therefore, is flat at $\mathrm{P}_{0}$ until the maximum volume of internally financed investment $\mathrm{K}_{0}$ is reached and is increasing thereafter.

Symmetrically, if the firm chooses a level of investment greater than $\mathrm{K}_{0}$, the risk of bankruptcy for the firm (borrower's risk) increases and the expected quasi rent decreases so that the actual stock price is lower than the original one $\mathrm{V}_{0}$. The schedule of the actual market price of investment goods (V schedule), therefore, is flat at $\mathrm{V}_{0}$ until the maximum volume of internally financed investment $\mathrm{K}_{0}$ is reached and is decreasing thereafter. 
The equilibrium volume of investment $\left(\mathrm{K}^{*}\right)$ and the equilibrium price of investment goods $\left(\mathrm{V}^{*}\right)$ are determined at the intersection of the upward sloping schedule representing the supply price of investment augmented by lender's risk and the downward sloping schedule which describes the market price of capital goods augmented by borrower's risk. Equilibrium investment depends upon the volume of internal finance and on the degree of borrower's and lender's risk which affect the slopes of the $V$ and $P$ schedules: $K^{*}=K\left(A_{0}\right)$. An increase in the availability of internal funds from $\mathrm{A}_{0}$ to $\mathrm{A}_{1}$ brings about an outward shift of both the $\mathrm{V}$ and $\mathrm{P}$ schedules and an increase of investment as shown in the figure.

The FIH is based on the distinction between hedge, speculative and Ponzi units:

"For hedge financing units, the cash flows from participation in income production are expected to exceed the contractual payments on outstanding debts in every period. For speculative financing units, the total expected cash flows from participation in income production when totaled over the foreseeable future exceed the total cash payments on outstanding debt, but the near term payment commitments exceed the near term cash flows from participation in income production, even though the net income portion of the near term cash flows (...) exceeds the near term interest payments on debt. A Ponzi finance unit is a speculative financing unit for which the income component of the near term cash flows falls short of the near term interest payments on debt so that for some time in the future the outstanding debt will grow due to interest on existing debt. Both speculative and Ponzi units can fulfill their payment commitments on debts only by borrowing (or disposing of assets)." (Minsky 1982, 22-3)

In a 'tranquil era' both borrowers and lenders expect future cash flows to be more than enough to validate debt. Asset prices, which incorporate these expectations, increase relative to the price of current output, stimulating investments which in turn drive up output, profits and employment. 
Minsky's cumulative processes, based on the interdependence between investment and profits come into play. The interdependence between investment and profits becomes the basis of an upward spiral involving all the variables, with the exception of borrower and lender risks, which fall with expansionary effects on investment. The increasing debt is thus associated with decreasing safety margins. As the real sector grows, the financial system becomes more and more fragile.

Banks are less cautious in extending credit and firms are less cautious in borrowing. As a consequence hedge units, that is, borrowers who are able to service debt in each and every period of the time horizon of their financial contracts, become speculative units. Borrowers who were speculative units, in turn, become Ponzi units, that is, they have to borrow in order to service outstanding debt. As the proportion of hedge units in the population of borrowers decreases, financial fragility increases.

In this heterogeneous agents' setting, the increase of aggregate financial fragility during the expansion is due to the change of the structure of the economy, the weight of hedge units shrinking over time. When the perception spreads that in the aggregate cash flows do not validate debt any more, the network of financial relations collapses and a financial crisis sets in. (Assenza et al. ibid. 189)

Minsky thus points to two drawbacks to the investment boom. First is its increasingly speculative nature. In the general euphoria, firms' debt commitments increase faster than profits and eventually exceed them. Expecting a future bonanza, firms start financing their principal by resort to debt (speculative financing) and then even interest payments (ultra-speculative or Ponzi financing). Thus an initially robust financial system becomes fragile. Second is that the persistence of the boom inevitably creates either bottlenecks in the financial system or inflationary pressures in the goods market that end up 
requiring a monetary restriction. In either case, the result is a rise in the rate of interest. (De Antoni ibid. 468-9)

The higher interest rate ends the boom, and the investment-profit-investment chain reverts to a downward spiral.

Several critical observations are already in place:

(1) Significantly Minsky's theory is a theory of the upper turning point. This aspect of his analysis provides an important element of analogy with the Austrian theory of the business cycle which is equally a theory of the upper turning point. In this respect Minsky's analysis is actually closer to the Austrian approach to the analysis of business cycles than to Keynesian insights and his status as a Keynesian along this dimension seems somewhat questionable.

(2) Minsky implicitly assumes that the actual investment gearing ratio between external and internal financing aligns itself with the desired, thus rising procyclically in the upswing and falling in the downswing. As investment increases, external financing grows faster than internal. As a consequence, the incidence of debt commitments on profits rises: finance becomes less hedge and more speculative. Minsky's line of reasoning here is questionable, however. The good performance of the real sector (profits included) might strengthen rather than weaken the financial sector. (De Antoni ibid. 465)

It is less clear, however, whether the Austrian theory relies on an assumption of this sort.

(3) Minsky's description of cumulative processes seems to fit the world in which we now live but a crucial question remains to be answered. What causes the initial increase in investment? The answer lies in Minsky's 'upward instability proposition' that 'stability—or tranquility—is destabilizing' and 'the fundamental instability is upward'. A period of tranquility (in which profits are 
systematically greater than inherited debt commitments) fosters greater confidence in the future, giving rise to a wealth reallocation from money to nonmonetary assets, which in turn drives up asset prices. The result is the initial externally financed increase in investment that triggers cumulative processes.

Still one might consider that the explanatory power or strength of the upward instability proposition is weak. (See further.)

At this point some additional insights can be provided by the alternative paradigm that is sometimes designated as "the Wicksell Connection" or "the Austro-Wicksellian Connection". Leijonhufvud had taught us that "the theory of the interest rate mechanism is the center of the confusion in modern macroeconomics." $(1981,131)$

According to Leijonhufvud:

"In Wicksell's theory of the cumulative process, the maladjustment of the interest rate - the discrepancy between the market rate and the natural rate-is the central idea. It is also the idea that motivates the analysis of changes in the price-level (or in nominal income) in terms of saving and investment. It is a simple but fundamental point. Use of the saving-investment approach to income fluctuations is predicated on the hypothesis that the interest rate mechanism fails to coordinate saving and investment decisions appropriately." (ibid. 132)

The Austrians clearly descend from the Wicksell Connection. The Austrian theory of the business cycle, which has been explained, clearly shows how a lowering of the market rate of interest below the natural rate will set the economy on an unsustainable growth path.

What about Minsky? Can Minsky qualify as belonging to the Wicksell Connection? This question will be further discussed in section 4. (a) hereunder. 
While one will look in vain for a single reference to Wicksell in Minsky's three books, on a number of occasions Minsky refers to Fisher's debt-deflation theory which clearly influenced his own debt-deflation theory. Minsky's debt-deflation theory emphasizes the role of the asset market. As in Fisher's explanation, distress selling can be self-defeating, and the asset market and distress selling feedback on each other. The fall in asset prices reinforces deflation via a negative wealth effect. This can result in a recursive debt-deflation process. The policy prescription is, clearly, to avoid the collapse of confidence in banks' liabilities by supporting the price of capital assets.

There are thus both macroeconomic and microeconomic aspects to financial fragility. At the microeconomic level, financial fragility means that elements on the liability and/or asset side of the balance sheet (plus off balance sheet assets and liabilities) are highly sensitive to changes in interest rate, income, amortization rate, and other elements that influence the liquidity and solvency of a balance sheet. In this case, not-usual fluctuations in these variables create large financial difficulties. The flip side of this high cash-flow sensitivity is a high reliance on refinancing sources (high refinancing risk) and/or asset liquidation at rising prices (high liquidation risk) in order to pay debt commitments. (Tymoigne and Wray 2014, 21)

At the macroeconomic level, financial fragility can be broadly defined as the propensity of financial problems to generate financial instability, that is, large disruptions in the financial systems that ultimately manifest themselves in the form of a debt-deflation. A debt-deflation is an economic situation that is characterized by a downward spiral of debts and asset prices in which indebted economic units desperately try to pay their debts by selling many assets at once, resulting in a massive drop in asset prices and so increasing the difficulty in obtaining enough funds to pay debts, leading to further distress sales. The large declines in asset prices negatively affect the net worth of otherwise sound 
economic units and so may propagate to economic sectors that were not previously n difficulty. Thus, financial fragility can be defined as the propensity of financial problems to generate a debt deflation. (ibid. 22)

\section{Discussion: Minsky versus the Austrians}

\section{4. (a) Minsky the Keynesian?}

Post-Keynesians distinguish themselves by two characteristics: they are the most active group emphasizing expectations and uncertainty as the driving force in the General Theory, and they combine this emphasis with intense concentration on their own choice of a favorite chapter, Chapter 17- "The Essential Properties of Interest and Money" — and on the role of money in "finance." (Meltzer 1988, 285) Minsky is no exception. Minsky believes, however, that Keynes' discussion in Chapter 17, though perceptive, is flawed because he does not explicitly introduce liability structures and the payment commitments they entail at this point, even though this entered into his definition of the precautionary demand for money. (Minsky 1975 [2008]), 77) As Minsky observes:

"At a crucial juncture in the argument, stagnationist and exhaustion-ofinvestment-opportunity ideas take over from a cyclical perspective in which investment, asset holdings, and liability structures are guided by speculative considerations." (ibid.)

Therefore Minsky describes his task as follows:

"In order to bring out the power of the ideas involved, we will undertake to adjust the argument of chapter 17 by explicitly considering liability structures and by setting the argument in a cyclical d speculatie framework. As modified 
by these considerations, the argument of chapter 17 gives us the ingredients for an explanation of a speculative investment boom and of why such a boom contains, in the development of a crisis-prone setup, the seeds of its own destruction. ( ibid. 77)

The idea of a boom containing "the seeds of its own undoing" is also very characteristic of typical formulations of the Austrian theory of boom and bust. The impression that Minsky's interpretation of the General Theory thus yields a variant of Keynesian business cycle theorizing not unlike and in some respects even close to that of the Austrians is not entirely mistaken. Nevertheless, the similarities will appear to be more superficial than real.

There exist several interpretations of the General Theory and major differences between interpreters about the meaning of the book and its central message.

According to one influential interpretation, "The General Theory is not about the business cycle." (Meltzer 1988, 250) Or rather, Keynes main difference, or one of his main differences with classical theory, is his concern with two issues, avoiding fluctuations and maintaining the optimum level of output. In Chapter 22 Keynes sketches the application of his theory to the business or trade cycle, but there is no implication that involuntary employment cannot persist since he believed that "we oscillate (...) round an intermediate position appreciably below full employment." (Keynes 1936 [1997], 254) He believed that the average level of output fluctuates around a (stable) level less than the maximum attainable.

Recently one author has reminded that Keynes and Hayek "not only shared far more theoretical ground than is typically realized but also held a deeper theoretical affinity with one another than with modern macro." (Goodspeed 2012, 2) The source of this affinity, it is argued, is the "Wicksell Connection" which is considered to be responsible for a fundamental convergence of their 
respective theories of money, capital, and the business cycle during the course of the 1930s but which effectively ended with Keynes and Hayek. In short, according to this view Keynes and Hayek were not quite the theoretical antagonists they were, and have since been, made out to be. (ibid. 3) What about Minsky in this respect?

The suggestion here will be on the one hand, that, despite some superficial similarities and analogies, especially concerning the role of money and banking institutions in the context of the business cycle, and despite other appearances to the contrary, Minsky's work does not fit very well into the Wicksell Connection, and on the other hand, that Minsky's own status as a Keynesian is somewhat questionable.

Keynes's belonging to the Wicksell Connection can be questioned too. Leijonhufvud $(1981,133)$ had proposed a grouping of macroeconomic theorists along two separate traditions labeled "Saving-Investment Theories" and "Quantity Theory." Keynes is categorized by Leijonhufvud as a Wicksellian but, as is also pointed out by Garrison $(1992,144)$, this is accomplished by patching together a new theory with ideas taken selectively from the Treatise and The General Theory. This interpolation between Keynes's two books is designated "Z-theory".

Garrison has proposed a different categorization of theorists which differs importantly from Leijonhufvud's in that "Keynes is transferred—on the basis of what he actually wrote - $\mathrm{t}$ o the other side of the Wicksellian watershed." According to Garrison “Keynes's chosen level of aggregation, together with is neglect of Wicksellian capital-market dynamics, establishes an important kinship to Fisher, Friedman, and Patinkin.” (Garrison 1992, 145)

Minsky's interpretation of Keynes differs markedly from both Leijonhufvud's and Garrison's. As claimed by Minsky's himself, his own interpretation is most 
faithful to the true vision and message of Keynes. He equally argues that a key to correctly interpreting Keynes resides in correctly understanding his conceptualization of the role of liquidity preference.

What is the Wicksell Connection?

Generally, the Wicksellian connection consists of three primary and tightly interrelated themes. The first is that money matters. The core of the Wicksell Connection, in contrast to all approaches of Walrasian descent, consists in the integration of real with monetary analysis. (ibid. $3 \mathrm{ff}$.) This ingredient is intimately related to the second element of the Wicksell Connection, namely, the identification of intertemporal coordination as the central problem in macroeconomics. The Wicksellian economy is one that gives full scope to potential coordination failures, with the "dark forces of time and ignorance", poised always to disrupt the coincidence of saving and investment. (ibid. 7 )

The third and final theme constituting the Wicksell Connection: the problem of intertemporal coordination of economic activity is inextricably bound up with questions concerning the dispersion, acquisition, and distribution of information and knowledge. (ibid. 8) Both Keynes and Hayek struggled to escape the invisible hand of the Walrasian auctioneer, with Keynes demonstrating how the coordination of individual economic activity could break down, while Hayek explored the conditions under which the market could ever get it right. Their theoretical analyses were thus not so much opposed to one another as they were just nonoverlapping in focus. (ibid. 8) As Garrison also clarifies, the point of the contrast between the two visions, which can be summarized in terms of their judgments about the existence—or non-existence—of the relevant spontaneous order, is a limited one. (Garrison 2000, 166)

A central element of the Wicksell Connection relates to the identification of intertemporal coordination and the role of the interest rate mechanism in this 
respect as the most important problem in macroeconomics. Although Minsky's analysis confirms the standard negative relationship between investment and the interest rates, in his scheme interest rates play a secondary role. Dominating the scene are the other determinants of investment, i.e. profit expectations and confidence. The future being unknown, Minsky assumes that expectations and confidence are myopically based on recent experience. (De Antoni ibid. 464)

Austrians do not reject any theorizing about the role of confidence or "animal spirits" per se but suggest that we need to look more carefully at the way in which Big Players in the economic system can affect confidence as a result of their dominance. They can boost confidence artificially, for example, through loose monetary policy and they can affect it adversely by creating policy uncertainty. (Koppl 2014, 130-1)

As De Antoni points out (ibid. 476) Minsky was not the interpreter of Keynes that he supposed himself to be. Experiencing the post-war renaissance instead of the tragedy of the Great Depression, he unaware applied Keynes' economics to a system whose fundamental instability is upward. In so doing, he discarded some important issues in The General Theory, for instance, the endemic nature of unemployment, the persistent damage of depression and above all the precariousness of recovery.

Minsky's cyclical rereading of The General Theory clashes with authoritative alternative interpretations, according to which it has an essentially static nature. In fact Minsky's "financial instability hypothesis" must be considered as an extension or a reformulation, not an "interpretation", of Keynes. (De Antoni ibid. 470)

Thus Minsky tried to insert dynamics into Keynes's monetary economy of production. There is no doubt that the ceiling and floor methodology developed by Hicks (1950) is at the heart of Minsky's methodology to deal with dynamic 
problems. (Ferri 1992) From an analytical point of view, this methodology implies piecewise linear relationships that generate acceleration in the dynamics within definite bounds. According to Minsky, this method is a perfect metaphor for the interplay between market forces and the role of policy and institutional changes. While the former tends to generate an explosive pattern, the latter introduces bounds. (Ferri 2010, 208)

Minsky's preoccupation with the upswing constitutes an important analogy between his theory of the business cycle and the Austrian theory. One could even say, without much exaggeration, that in this crucial respect Minsky's theory is conceptually closer to the Austrian theory than to the Keynesian approach: much like the Austrian theory, Minsky's theory is a theory of the upper turning point. Keynes' perplexities instead focus on the lower turning point. Minsky "combats" the upswing, Keynes the downswing. (De Antoni ibid. 473)

This circumstance perhaps suggests certain other similarities or even a certain affinity between the Austrian theory of the business cycle and Minsky's approach to the understanding of financial instability. This matter will be examined in more detail in further sections. It will appear that the analogies and similarities between the two approaches are rather superficial and that fundamental conceptual divergences between the two approaches subsist.

\section{4. (b) Providing macroeconomics with micro-foundations}

Both Minsky and the Austrians are sensitive to the requirement that macroeconomic theories should be provided with adequate micro-foundations.

In his doctoral dissertation Minsky had already emphasized "the need to relate aggregate analysis to the behavior of economic units. In particular, the relation 
between investment and the behavior of individual firms is investigated." (Minsky 2004, 17) Without any doubt he thus intended to embrace a disaggregated approach to business cycle phenomena. Minsky considered his approach in the dissertation to lay the micro-foundation for determining macro performance. The dissertation is a microeconomic analysis of firm behavior encompassing the various decision-making processes regarding entry, market structure, expansion, vulnerability and survival. A firm's financing relations affecting each and every stage of the firm's development are dependent on its capacity to honor obligations in meeting commitments made today with cash flows received in the future which in their turn are dependent on the impact the business cycle has on the firm. (Papadimitriou 2004, x)

Austrian theorizing has also been very sensitive to issues of excessive aggregation and Austrian economists have generally been critical of conventional macroeconomists' primary focus on aggregate magnitudes and their abstracting from individual market participants and their interactions.

But whereas Minsky develops the linkage of business investment with finance in the microeconomic sphere by extending the conventional neoclassical theory of the firm, Austrians base their unique macroeconomics on the concept of an inter-temporal structure of production.

In the Austrian approach the attempt to disaggregate the macro-economy and macroeconomic theorizing manifests itself most clearly in the central role accorded to the capital structure of the economy and to capital theory. (See further under f.)

In Minsky's theory of investment determination, all the determinants of investment can be firm-specific. Moreover, although Minsky's theory of investment determination can be formulated without explicit reference to heterogeneity, at a deeper and more significant level Minsky's ideas can be 
properly expressed only in an heterogeneous agents' setting. The FIH is based on the distinction among hedge, speculative and Ponzi units.

Some researchers consider that the role of heterogeneous financial conditions is the part of Minsky's legacy that may be the cornerstone of a new research agenda. (Assenza et al. 2010) Assenza et al. (2010) also provide an example of a macroeconomic model in which firms are characterized by heterogeneous financial conditions at the firm level.

No doubt contributions like these embody an attempt to disaggregate the business cycle, that is, to implement a disaggregated approach to the study of business cycles by looking at how the structure of the economy evolves over the course of the cycle.

Austrians' main objection to Keynesian macroeconomics has often related to the excessive level of aggregation exemplified in Keynesian macroeconomic models, but clearly Keynesianism—at least post-Keynesianism—is evolving...

Such attempts to disaggregate the business cycle undeniably constitute an element of similarity with the Austrian approach but again this similarity is superficial to the extent that the ways in which the business cycle is disaggregated in Austrian conceptual models start from quite different assumptions.

In Minsky, the necessity of microfounding the analysis is clear in his study of the determinants of investments in a monetary economy and in an uncertain environment, as well as in the inquiry about the interaction between cash flows and financial commitments. What really matters in Minsky's framework is more the presence of monetary and financial links with the real economy, and the fact that the reliance of firms on debt finance makes capitalism intrinsically unstable, than the presence of a precise investment function. (Bellofiore and Ferri ibid. 23-4) 
The fundamental method in the Austrian economic theory is what has come to be called "methodological individualism". Economic events can only be explainable in terms of individual human actions. This means that the trade cycle theory should in essence be a microeconomic explanation of macro events. The phenomena of the trade cycle should be explainable in terms of the responses of individuals in the system to price signals. (Cochran and Glahe 1999, 73-4)

Again the similarity is rather superficial, however. As Bellofiore and Ferri explain:

“Although microfounded, Minsky's analysis must be interpreted more as a macrofoundations of microeconomics than vice versa. This means that his route has been macro-micro-macro: he starts from the determination of aggregate demand and total gross profits in the period, together with the liability structure inherited from the past; then he looks at the micro consequences of the current ratio of gross capital income and cash-payment commitments on individual choices about financing and investment; and finally he reconstructs the macro effects on the system's evolutionary dynamics. In this perspective, his utilization of the Kaleckian profit equation represents both a confirmation of this thesis and a deepening of previous writings, (...).” (Bellofiore and Ferri 2001a, 24)

\section{4. (c) Critique of mainstream equilibrium theorizing and use of equilibrium concepts}

Both Minsky and the Austrians have criticized variants of mainstream equilibrium theorizing but while Minsky's rejection of the "crutch" of equilibrium is total and uncompromising, the Austrian theory retains an equilibrium concept in an essential way. (Cochran and Glahe 1992) From the 
Austrian viewpoint, a proper but limited use of an equilibrium concept as a benchmark leads to a dynamic disequilibrium theory of a cycle. (Cochran and Glahe 1999, 152)

On the other hand, Austrians are methodologically at odds with neoclassical equilibrium theory. They eschew mathematical formalism, especially of the mechanistic type, preferring a historical narrative of events, reflecting their perception that events form part of dynamic processes that more often than not are out of equilibrium. (Simpson 2013, 135)

The traditional Austrian theory of the cycle has also been characterized as profoundly deterministic: the arrival situation is a stationary equilibrium determined in a univocal manner on the basis of real variables (preferences, techniques and initial endowments of agents) and the ultimate cause of the cycle is purely monetary (bank policy). (Gloria-Palermo 1999, 74)

In Minsky's view, the traditional re-equilibrating price mechanism has to be replaced by quantity mechanisms that exert cumulative effects on one another. After reaching their maximum development, the resulting tendencies wane and reverse. Advanced capitalist economies thus cyclically fluctuate in a permanent disequilibrium. (De Antoni ibid.466)

On this issue again the approaches of Minsky and the Austrian School may seem superficially similar but in fact they differ substantially. As pointed out, the Misesian cycle theory was a disequilibrium theory which nevertheless made a limited but essential use of an equilibrium concept. A tendency towards equilibrium is a key feature of the Austrian cycle. (Cochran and Glahe 1992)

\section{4. (d) Price-theoretic Aspects}


The Austrian theory of the business cycle has a sound basis in price theory. The interest rate is a price. It is the price that strikes a balance between people's eagerness to consume now and their willingness to save for the future. The logic of the theory is firmly anchored in the notion that the price system is a communications network. A miscommunication in the form of an interest rate held below its market, or "natural" level by central-bank policy sets the economy off on a growth path that is inherently unsustainable. Given actual consumer preferences and resource availabilities, such a policy-induced boom contains the seeds of its on undoing. (Van den Hauwe 2009, 165)

In the capital-based analysis the market process set in motion by credit expansion does not depend in any essential way on there being a change in the general level of prices. (Garrison ibid. 71) Hayek had already disputed the ideas of Fisher and his followers that money acts upon prices and production only if the general price level changes.

A distinguishing characteristic of Minsky's work is his contribution to the elucidation of Keynes's price theory. Many believe that Keynes's work was devoid of price theory, but Minsky is one of a small group of post-Keynesian economists who has insisted on the importance of the price-theoretic aspects of Keynes work, and continued to try to develop this aspect of the Keynesian system.

The Austrian theory of the business cycle incorporates the Wicksellian insight that the difference between the real (or natural) and nominal (or market) rate of interest is the source of a cumulative process initiated when the former remains fixed while increases (decreases) in money cause the latter to decrease (increase). From this perspective the Austrian theory could be characterized as a "two rate" model to explain cyclical fluctuations. 
Minsky's theory, however, comprises a "two price" model which is of a very different distinctive nature. According to Minsky, there are really two systems of prices in a capitalist economy - one for current output and the other for capital assets. When the price level of capital assets is high relative to the price level of current output, conditions are favorable for investment; when the price level of capital assets is low relative to the price level of current output, then conditions are not favorable for investment, and a recession-or a depressionis indicated. Business cycles result from a dance of these two price levels, even as the price of a unit of money is fixed at one. (Kregel 1992, 87; Minsky 1986 [2008], 160)

The fundamental relative price in a capitalist economy is thus the relation between the price of capital assets and the price of current output. This two-price model is the analytical tool by which Minsky integrates his theory of money and finance into his theory of investment.

The price of capital assets is intrinsically disconnected from their cost of production. The notions of a basic independence and of a greater instability of the price of capital assets relative to output prices follow from Minsky's tracing back of the demand price of new capital goods to the market price of stocks.

The demand price of the flow of new capital goods depends on the market price of the stock of capital assets on the stock exchange. Investment will take place if the demand price is higher than the supply price.

The supply price has two main components: purchase price plus financing costs. The purchase price comes from the price system for current output, because capital assets are part of current output; thus this price is determined as a markup over labour costs.

Finance costs include explicit costs (interest rate and fees) and implicit costs (increased supervision by lenders). These tend to rise with the quantity of 
investment because lenders perceive greater risk associated with larger loans what Keynes had called lender's risk.

The supply price must be weighed against the demand price-which mainly comes out of the asset price system. This is the price one is willing to pay for an asset, including capital. The main determinant of demand price is expected profit. However, expected profits are in the future and are uncertain. They are discounted before they can be compared with supply price. If the capital asset will have to be at least partially externally financed, the demand price must include a margin to compensate for what Keynes called borrower's risk. The greater the quantity of external finance required, the greater the perceived borrower's risk because of higher payment commitments.

As we have pointed out, taking into account the internal financing constraint, the possibility of raising borrowed funds and the conditions shaping external finance of positions in capital assets, the intersection of the demand price function with the supply price function of new capital goods determines investment demand and production.

Arguably Minsky's two price systems analysis is a better way to analyze the financial capitalist economy than is the consumption/investment approach of the orthodox textbooks.

First, there is the price system for current output, which includes consumption, investment, government, and export goods and services. Prices of current output are essentially set as a mark-up over labour costs. Of course, market power allows the individual firm to set price at a greater mark-up. At the micro level, the mark-up distributes profits among firms, with market power leading to a greater share of profit flows.

The price of current output represents the "carrier of profits" and the means for validation of debts. Current output prices are determined by investment 
expenditures and supported by Big Government expenditure flows. Big government is, in reality, a support system for private sector current output prices and profits. The second system of prices (of capital assets) helps determine the first set through its impact on investment. Since the decision to hold capital assets is also a decision concerning their financing, investment represents a decision about both asset and liability structures. (also Kregel ibid. 87) The endogenous generation of instability is built around the linkage between current output prices and the demand for investment and capital goods prices. Minsky had to go back to the Treatise to find the two-price trail. There are two levels to the "two prices" approach. The first level, presented in the Treatise, distinguishes between the prices of current output and capital goods output; the second level, added in the General Theory, distinguishes the prices of new and existing capital assets from the prices of new and existing financial liabilities. The first is sufficient to express the financial instability hypothesis, while the second is necessary to analyze fully how a change in asset prices will affect confidence in bank liabilities and how it may or may not lead to financial panic. (Kregel ibid. 95)

\section{4. (e) Monetary Aspects}

\section{4. e.1. Inter-dependence between real and monetary aspects}

Economists commonly distinguish between monetary and non-monetary theories or explanations of the business cycle. While Keynes' theory of the cycle has been characterized as a real theory (Meltzer 1988, 179), both Minsky's theory and the Austrian theory of the business cycle can be characterized as belonging to the monetary approach to the explanation of business cycles. 
In contrast money has no role in, e.g., real business cycle theory (RBC). Real business cycle theory is thus an example of a non-monetary theory of the business cycle. The theory attributes business cycles to real or supply shocks, such as changes in technology. (Rabin 2004, 208)

According to the RBC theory, exogenous fluctuations in the level of total factor productivity make steady reallocations of the factors of production necessary in order to maintain an efficient economic allocation. Observed business fluctuations are explained as the efficient outcome of the interaction between agents' maximizing behavior. (Lutz 2002, Chapter 5)

According to Minsky business cycles are both monetary and real phenomena. The artificial separation between monetary and real phenomena is inconsistent with the hypothesis that the analysis of the determinants of investment is necessary for business cycle theory. As investment behavior is related to prices (the interest rates) which are determined, at least in part, in the financial and money markets, no theory of the business cycle which does not consider the interrelations between financial and real factors is consistent with the key hypothesis as to the significance of investment behavior. (Minsky 2004, 87) Minsky concluded that the financing of a firm's expansion may result in a deterioration of its survival conditions. Therefore the liquidity crises of the downswing can be imputed to the development of the expansion. (ibid. xiv) As we have explained, and as is reminded by Machlup's well-known statement, "( $t$ )he fundamental thesis of Hayek's theory of the business cycle was that monetary factors cause the cycle but real phenomena constitute it." (Machlup 1976, 23)

While Austrians would of course not subscribe to the view that interest rates are determined in the money and financial markets, both Minsky and the Austrians thus agree that any adequate explanation of the business cycle will highlight 
both the monetary and the real factors involved. But, again, the specifics of the explanations are quite different.

\section{4. e.2. The non-neutrality of money}

Minsky's work is best understood as a contribution to the general theory of money. In particular his work represents the most significant American contribution of his generation to the Banking School tradition of monetary thought that sees money arising as the natural byproduct of business finance. (Mehrling 1999, 150)

The dominant microeconomic paradigm is an equilibrium construct in which initial endowments of agents, preference systems, and production relations, along with maximizing behavior, determine relative prices, outputs, and an allocation of outputs to agents. Money and financial interrelations are not relevant to the determination of these equilibrium variables. An implication of these constructs in the dominant microeconomics and the core of the dominant macroeconomics is that money and finance are neutral. In these dominant models money is a veil. (Minsky 1993, 77)

As Friedman put it, although money and other institutions complicate the analysis, all the important characteristics of a modern capitalist economy are supposed to be contained in the simple model of the barter economy. (Minsky 1986 [2008], 129)

But in the real world, in the financial capitalist world, money is the key institution. It is endogenous, created during normal economic processes. Minsky emphasizes that, most importantly, money is created in the process of financing positions in assets. Banks increase the money supply whenever they share the 
belief of the borrower that positions in assets or financed activity will generate sufficient cash flows. If the future turns out to be worse than expected, it may be impossible to meet commitments. So money and nominal financial commitments matter.

The conventional economic paradigm is thus not the only way economic interrelations can be modeled. Every capitalist economy can be described in terms of sets of interrelated balance sheets. At every reading of the balance sheet the financial instruments can be interpreted as generating two sets of time series: the liabilities generate payment commitments, and the assets generate expected cash receipts. Balance sheets relations link yesterdays, todays, and tomorrows: payment commitments entered in the past lead to cash payments that need to be executed now as well as future cash payments, even as liabilities are taken on now that commit future cash flows. In this structure the real and the financial dimensions of the economy are not separated: there is no so-called real economy whose behavior can be studied by abstracting from financial considerations. This system, linking yesterdays, todays, and tomorrows both financially and in terms of the demand for and supply of goods and services, is not a well-behaved linear system. Furthermore, the presumption that this system has an equilibrium cannot be sustained. This modeling of the economy leads to a process in time that generates a path that can fly off to deep depressions and open-ended inflations, even in the absence of exogenous shocks or strange displacements. In this model money is never neutral. (Minsky ibid. 78)

The non-neutrality of money in this version of Keynesian economics is due to the difference in how money enters into the determination of the price level of capital assets and of current output, that is, investment goods and consumption goods in the simplest case. (ibid. 79) 
Austrian insights concerning the non-neutrality of money derive from an entirely different strand of literature. Austrians are inclined to emphasize "Cantillon effects" of changes in the money supply, so called after Richard Cantillon ([1755] 2001). When new money enters the economy, perhaps as the result of gold discoveries under a gold standard, perhaps as the result of credit expansion under a fiduciary system, the new money does not penetrate all sectors of the economy at a uniform pace. It enters in particular sectors and in particular ways. Some prices and incomes are bid up first. The early recipients of the new money tend to enjoy increased buying power. Gradually the new money circulates around and penetrates all sectors of the economy, but it reaches some sectors quite late. Selling prices and nominal incomes in those sectors do not keep pace with the general inflation, and their real incomes and purchasing powers suffer. A similar story applies in reverse to withdrawals of money from circulation. The process does not work uniformly. Changes in the money supply distort, at least transitionally, the pattern of relative prices and incomes and consequently distort the patterns of resource allocation and production. Such distortions form one reason why Austrians take a micro approach to theory and disdain theorizing in terms of aggregates and averages. (also Yeager 1988, 95)

Monetary economists working in the tradition of Cantillon ([1755] 2001) and Wicksell ([1936] 1965) recognize that (1) since the process by which real cash balances are adjusted and the process by which relative prices are established are not two separate market processes, that is, the demands for real goods and services are affected as economic agents seek to adjust their cash balances to their optimal level, as monetary changes will cause individual cash balances to differ from their optimal level; monetary changes affect the relation between the demand for and the supply of goods and thus also their relative prices; and that (2) the way money enters the economic system will affect the dynamic adjustment process even in a predictable way. As recognized earlier by Cantillon 
([1755] 2001), the demands of those who are initially affected by the monetary disturbance change before the demands of those who receive additional money balances only as the effects of the monetary change spread through the economy.

The latter point concerning the significance of the point of impact of monetary changes and its predictability relates directly to the basis of the Hayek-von Mises theory of the trade cycle: if monetary changes enter the economy as changes in the availability of credit, as may be expected to be the case in an economy with a fractional-reserve banking system, these changes will alter the money rate of interest relative to the equilibrium rate and disrupt the balance between the supply of and the demand for capital.

It is the effect of such monetary changes on the money rate of interest relative to the natural rate of interest and the consequent effect on the decision to invest relative to the decision to save that constitute the saving-investment problem that is at the basis of the Austrian natural rate approach to the monetarytransmission mechanism.

Monetarists held, as the classics had done, the view that money is both neutral and super-neutral in the long run. Neutral money means that an increase in the level of the nominal money supply only causes an increase in the aggregate price level and does not affect any real economic variables; the term "supernatural" is an extension of this, which implies that an increase in the rate of growth of the money supply will only affect the rate of inflation, and not any real variables. (Smithin 2013, 47)

Friedman's strategy with respect to this problem was essentially to concede the impact of money on output for the short run, but not for the long run. It was held that monetary changes can be non-neutral in the short run, but are always neutral (and super-neutral) in the long run. With this argument, monetarism was thereby 
able to retain the basic proposition about the long-run relationship between money and inflation, while at the same time providing a viable explanation for business cycle fluctuations. (ibid. 65) The Austrian position in this respect is clearly distinct from the monetarist, however. As regards the impact of monetary stimulus, money is non-neutral even in the long run. (Ravier 2013)

\section{4. e.3. The endogeneity of money}

At the most general level, endogeneity implies that the supply of money is not independent of demand. Often, however, the exogeneity-endogeneity distinction has referred to the ability of the central bank to control the money supply. (Wray ibid. 169) Post-Keynesians do not accept money exogeneity, even in the control (or weak exogeneity) sense.

It is possible to conceive of a continuum of possibilities, with strict exogeneity at one extreme and strict endogeneity at the other. In the case of strict exogeneity, the money supply curve would be vertical in interest-money space-this is the so-called "verticalist" approach. Athough this is the way the money supply curve is often drawn in orthodox textbooks, even most orthodox economists admit that the central bank accommodates shifts in money demand to prevent wide fluctuations of interest rates.

At the other extreme lies complete endogeneity, where money supply completely accommodates money demand as the Fed pegs the interest rate. This is the "horizontalist" position which has been adopted by, among others, Kaldor. Minsky's approach to money implies an upward-sloping money supply curve. There are thus two main strands of the endogenous money approach: the horizontalists and those who accept an upward-sloping money supply curve. The 
key difference between these two strands is over the determination of interest rates: the horizontalists argue that interest rates are exogenously set by the central bank, while the other strand accepts an endogenously determined interest rate. This second approach emphasizes uncertainty, liquidity preference, profitseeking behavior, and innovations in addition to central bank behavior. (Wray ibid. 174)

Post-Keynesians have also emphasized the ability of financial institutions to economize on reserves and to innovate to escape attempts by the central bank to use quantity controls. Financial innovation and liability management give banks great flexibility in determining the quantity of money. These activities play a central role in Minsky's FIH for they contribute to the transition from a robust financial system to a fragile one in which liquidity has become stretched.

Innovations allow an existing quantity of high-powered money to support greater expenditures. This can be linked to an upward-sloping velocity function: as interest rates rise, banks will expand credit in response to profit opportunities. Thus, any given quantity of money, narrowly defined, could permit more spending as credit is created. Furthermore, innovations can shift the velocityinterest rate function so that velocity might increase even without rising interest rates.

Austrians and Keynesians seem to by and large agree on the endogeneity of money issue. Garrison writes that irrespective of the tools used by the Federal Reserve to change the money supply, the fact that is of overriding significance for the application of capital-based macroeconomics is that these alternative policy tools are simply different ways of lending money into existence. (ibid. 68)

According to Cochran and Glahe (1999, 75 fn) "Hayek's view of the money supply process expressed in his discussion of endogenous versus exogenous 
theories is compatible with the Post-Keynesian theory of money." Godley and Lavoie $(2012,127)$ write that " $(t) h e r e$ is a school of thought that has long been arguing in favour of endogenous money. This line of thought goes back to the writings of Thomas Tooke and the Banking School, and has been present in the history of economic thought ever since. It can be associated with the Swedish economist Knut Wicksell as well as several economists of the Austrian tradition, such as von Mises and Friedrich Hayek in the 1920s and 1930s."

Hayek had criticized von Mises's theory, however, as being exogenous. The von Mises cycle starts with a monetary injection initiated by the banking system; the market rate is decreased below the natural rate as banks extend additional loans. The cycle results from an active intervention into the market process. In the Hayekian model the cycle may start in this manner, but it may also start if banks fail to increase the market rate when the natural rate increases, i.e. if investment demand increases and banks are confronted with an increased demand for funds. (Hayek $\quad$; Cochran and Glahe ibid. 75)

In making the endogenous-exogenous distinction, Hayek was arguing that cyclical activity will be a standard feature of an economy with an elastic currency; an economy where the supply of money either wholly or partially responds to changes in the demand for money or the demand for credit. (Hayek )

The Austrian theory of boom and bust, despite its explicit focus on saving, investment, consumption, and production time, is equally, root and branch, a monetary theory. (Garrison ibid. 52)

Even if Austrians and Post Keynesians will thus by and large agree with respect to the endogenous nature of money, the following distinctive theoretical ingredients seem essential to the Austrian position: 
(a) Consistent with Hayek's understanding, capital-based macroeconomics treats money as a "loose joint" in the economic system. The Austrian theory of boom and bust, which presupposes an essential loose-jointedness, identifies a systematic misallocation of resources that could not possibly characterize a tight-jointed system. Policy-induced inter-temporal disequilibrium is the essence of the unsustainable boom.

(b) The market process set in motion by credit expansion does not depend in any essential way on there being a change in the general level prices. (Garrison ibid. 73) The relative-price changes that initiate the boom are attributable to a monetary injection. The focus is on the point of entry of the new money and the consequent changes in relative prices that govern the allocation of resources over time. (ibid. 67)

(c) The different aspects of the market process set in motion by a monetary injection are not mutually compatible. The conflicting aspects of the market process can have their separate real effects before the conflict itself brings the process to an end. The very fact that the separate effects are playing themselves out in inter-temporal markets means that time is an important dimension in the understanding of this process. (ibid. 68)

(d) The Austrian theory is a malinvestment—rather than an over-investmenttheory of the business cycle. Policy-induced malinvestment is the unique aspect of the theory. Malinvestment - the misallocation of resources in the direction of stages remote from consumption - has to be taken to be the unique and defining aspect of Austrian theory, even if over-investment is a critical enabling aspect of the theory. (ibid. 81)

(e) To the extent that the processes of money injection, credit expansion and the resulting malinvestment and misallocations of resources are initiated by a "monetary authority", i.e. essentially an extra-market force, there is not the least 
implication —not even the mere suggestion - that cyclical instability of a monetary origin is necessarily inherent in or "endogenous" to market-based forms of capitalism. Historically observed instances of cyclical instability and business cycles are phenomena inherent in mixed economies, not in entirely market-based economies. (Ikeda 1997, 131-2 and passim) Moreover, hypothetical market-based monetary systems from which the historically observed recurrent financial instability would be absent are theoretically conceivable and their working characteristics have been described in some detail. (Huerta de Soto 2012) The solution to the problems posed by financial instability and business cycles are thus not Big Government and a Big Bank supposedly acting as stabilizers but monetary decentralization and free banking.

(f) It follows from the previous observation that business cycles-and in particular also their recurrent character-are to be linked not merely to monetary policy narrowly conceived, but more broadly and more fundamentally to the monetary regime or monetary-institutional framework or context that is in place. The Austrian approach thus comprises a significant comparativeinstitutional dimension.

\section{4. e.4. The role of credit creation/expansion}

The quantity of money can't be exogenously determined as it is created as a result of private profit-seeking behavior. Neither can money be neutral since its creation is tied up with the process of creating and controlling capital assets. Nominal values (money prices) matter. (Minsky 1986 [2008], 223)

Money creation is thus intimately tied to the essential feature of capitalismcapital accumulation. Money is created in the process of financing investment 
and forces the surplus which is necessary to allow capital formation. More fundamentally, credit creation is the means by which society ensures that the workers cannot purchase the total product. Credit creation gives purchasing power to entrepreneurs so they may finance capital accumulation. As Minsky argues, the markup in the consumption goods industry guarantees that workers in the investment goods industry can obtain consumption goods, while spending on investment goods generates a surplus over labor income. (Minsky 1986, Chapter 7)

The money thus created fulfills two other important functions: it serves as a medium of exchange, and it can be held as insurance against an uncertain future.

Now it is important to note how this analysis importantly differs from the Austrian analysis:

(1) The Austrian analysis also comprises a non-neutrality of money proposition but as we have seen the Austrian insights into the non-neutrality of money are derived from an entirely different tradition. The Austrian analysis of this issue derives from the work of, among others, Cantillon and Wicksell. This author hasn't been able to locate one single reference to the work of either Cantillon or Wicksell in Minsky's three books.

(2) The Austrian analysis is built around the conceptual and theoretical distinction between sustainable growth (or capital accumulation) and unsustainable growth (based on credit expansion). Whereas sustainable capital accumulation derives from genuine saving, credit expansion leads to unsustainable growth, i.e., boom and bust.

Money and credit created in the process of capital formation is what in the Austrian theory is designated as a form of credit expansion. Austrians would therefore object to the proposition that capital accumulation as the essential feature of capitalist economies is essentially and necessarily tied to credit 
expansion and money creation as stated by Minsky. Capital formation requires genuine saving. In this context Mises made the useful distinction between commodity credit and circulation credit. Commodity credit cannot be expanded. (Mises (1949 [1966], 433-4)

Moreover, from the Austrian viewpoint, cyclical and financial instability are not inherent in capitalist economies but are essentially phenomena of mixed economies. Austrians can question the adequacy of Minsky's identification of the relevant institutional context. Minsky states or at least strongly suggests that the adjective "capitalist" refers to free market economies but all historical capitalist economies are actually mixed economies and the instability that is observed in history is actually the instability of a mixed system. At the theoretical level this circumstance may still seem to leave open the answer to the question whether financial instability is conceivably inherent in free market economies or whether it is actually a consequence of government intervention. Austrians generally argue that the business cycle is actually generated by public authorities' intervention in market processes.

The Austrian analysis of the business cycle thus derives from the fusion of monetary theory with capital theory, i.e., the introduction of a theory of heterogeneous capital into the theoretical analysis of business cycle phenomena. This fusion or integration of monetary theory and capital theory is unique to the Austrian approach. 


\section{4. (f) The centrality of capital and capital theory}

In Minsky's theoretical construction too considerations relating to time and capital clearly play an important and essential role. He concluded his Stabilizing an Unstable Economy (Minsky 1986 [2008], 369) with the consideration that "(t)he essential Keynesian result, that capitalism is flawed mainly because it handles capital poorly, nowhere enlightens current policy actions (...)" and that "Keynes recognized the flaws in capitalism because he, more than his predecessors, contemporaries, and successors, understood the financial and time-related aspects of a capitalism that uses capital."

In the Austrian vision, and as envisioned early on by Menger ([1871] 1994, 8087), the economy's production process is disaggregated into a number of temporally sequenced stages of production. Replacing the single investment aggregate with temporally sequenced stages that make up the economy's capital structure is what will provide a basis for a substantive distinction between sustainable growth and unsustainable boom.

Austrians thus work at a lower level of aggregation in order to allow for the output of the investment-goods sector and of the consumer-goods sector to move relative to one another and even to allow for differential movements within the investment-goods sector.

Considerations of capital structure allow the time element to enter the theory in a fundamental yet concrete way. (Garrison ibid. 7-8) The macroeconomic significance of the fact that production takes time suggests that, for business cycle theory, capital and money should get equal billing. (ibid. 8) The critical time element manifests itself in the Austrian theory as an intertemporal capital structure. (ibid. 8) Attention to the intertemporal structure of production is unique to Austrian macroeconomics. The market economy, in the judgment of 
the Austrians, is capable of tailoring intertemporal production activities to match intertemporal consumption preferences. (Garrison 2005, 480-1)

Hayek felt that the existence of unemployed resources should be explained not assumed. The emergence of the crisis and the corresponding idleness of existing resources depend, in Hayek's model, on certain characteristics and aspects of capital that are emphasized in "Austrian" capital theory but are ignored in typical macroeconomic models. In such models, capital is generally treated as a homogeneous mass adaptable to any use; all capital is non-specific. Four main characteristics of capital that are ignored in most macroeconomic models but appear consistently in Hayek's writings are: (1) capital goods are nonhomogeneous; (2) capital goods are non-permanent resources; (3) capital goods (and other resources) are complementary; and (4) capital goods (as well as original factors of production) can be either specific or non-specific. The more specific a resource is, the less mobile it is. (See also Cochran and Glahe ibid. Chapter 8 and the references there.)

\section{4. (g) The role of uncertainty, institutional context and liquidity preference}

\section{4. g.1.Uncertainty}

According to Minsky the essential difference between Keynesian and both classical and neoclassical economics is the importance attached to uncertainty. (Minsky 1982, 128) Minsky believed that the financial strategies followed by firms change over time, sometimes as a result of conscious decision making and sometimes because of unforeseen changes in circumstances. Like Keynes, Minsky believed that the future is essentially unknowable and beliefs regarding the future are highly subjective. In fact, Minsky even goes further than Keynes 
in arguing that individuals often act irrationally, excessively exuberant during good times and excessively panicky during bad times.

Psychology and financial fragility, as measured by the microeconomic financial fundamentals of firms play the primary roles in driving business cycles. (Knoop 2008, 85)

Svetlova and Fiedler (2011) analyze the views on the meaning of uncertainty and probability of Knight, Keynes and Shackle in light of the financial crisis. Austrians generally recognize that whereas risk analysis, whether objective or subjective, is essentially a weighting of possibilities already known, genuine uncertainty allows for the unpredictable growth of these possibilities and thus for "gaps" in agents' probability distributions. Since action takes place in real time, any activity designed to deal with uncertainty may merely transform that uncertainty. The source of uncertainty is thus endogenous in a world in real time. (O’Driscoll and Rizzo 1996, 64 ff. and Ch. 5) At a fundamental theoretical level, Ludwig von Mises's views on probability were closer to the spirit of Keynes's philosophy of probability than to the frequency interpretation of Richard von Mises. (Van den Hauwe 2011) The views of post-Keynesians and Austrians on the meaning and role of uncertainty thus seem to converge. As we will see further, however, they take diametrically opposed positions as regards the relationship between real-world uncertainty and the (role of the) institutional context. (See further.) 


\section{4. g.2. The role of liquidity and liquidity preference}

To recognize the endogeneity of money resurrects the Keynesian concept of liquidity preference as a central cause of the volatility of macroeconomic activity. (Wray 1992)

In the General Theory, Keynes limits the effects of the needs for liquidity to the price of financial liabilities, that is, the interest rate that is charged for the creation of bank accommodation. (Kregel 1992, 95) The separation of the determinants of the prices of assets and debts - or the distinction between the marginal efficiency of capital and liquidity preference - may be called the great innovation of the General Theory. (ibid. 94)

The sharp changes in the money values of assets and liabilities which occur independently of any change in their underlying real productive potential can now be explained via liquidity preference leading to a fall in liability prices as agents shift their holding of financial liabilities to more liquid assets. This, then, spills over into firms' liabilities which are assets for the banks, and leads the banks to reduce accommodation in an attempt to restore the liquidity of their balance sheets. There is a subsequent rise in the interest rate and a fall in the discounted value of anticipated future profits, as well as a downward revision in expectations. Both lead to a revision of capital asset prices represented by a reduction in the marginal efficiency of capital which reduces investment expenditures. (ibid. 94) Keynes himself stated explicitly, however, that "Liquidity-preference (...) does not increase until after the collapse in the marginal efficiency of capital.” (Keynes 1936[1997], 316)

According to Minsky, there exists a functional relation between the price of a particular or a representative capital or financial asset and the quantity of money. Normally the price of a capital asset is a rising function of the quantity 
of money, for as the quantity increases the value of the insurance in money decreases. As the price of money is always one, this implies that the price level of income-yielding capital assets increases. The function shifts as experience changes expectations of the cash flows that capital and financial assets will yield and the worth attached to holding money. (Minsky 1986 [2008\$, 203-4)

The prices of capital assets and debts in different proportions are related to the supply of money, which only yields an income in kind $l$ (liquidity premium) and which, by definition, has a price of 1 . The prices that are generated are the prices of the units in the stock of assets, both capital assets and financial assets. (Minsky 1975 [2008], 88-9)

Minsky's model is a two-price- level model, where, in the short run, current output and capital-asset prices depend upon different market processes. Whereas wages and the current costs of producing output, and thus the offer prices of current output, move sluggishly, the prices of units in the stock of capital assets and, more directly, the price of equity shares traded on the exchanges can move rapidly. Thus the relation between the two price levels can change quite quickly; we have a price level of current output which is in principle sluggish, and a price level of capital assets which is in principle volatile. (ibid. 89)

Austrians have in general been critical both of liquidity preference theory and of the monetary theory of the interest rate. Austrian economists question both the central place of liquidity preference in Keynes's account of the business cycle and the legitimacy of the liquidity preference theory itself. According to Garrison, "(l)iquidity preference, which is sometimes seen as the sine qua non of Keynesianism, plays a secondary role-in terms of both causation and chronology—in Keynes's account of the business cycle." (ibid. 150) According to Rothbard, the Keynesian doctrine of liquidity preference suffers from the mathematical-economic sin of "mutual determination." (Rothbard 2004 785-92) 
Following Lachmann (1937), Rothbard also points out that in the presence of an organized forward or futures market for securities, speculative bearishness would indeed cause at least a temporary rise in the rate of interest, but accompanied by no increase in the demand for cash. He concludes that "any attempted connection between liquidity preference, or demand for cash, and the rate of interest, falls to the ground." (ibid. 792)

In general Austrians thus reject the Keynesian preoccupation with the relatively unimportant problems of the loan market as well as with liquidity preference or the demand for money to hold "for speculative purposes". (Rothbard 1962[2004], 454-5, 687 ff.) Whereas Keynes criticized Mises's theory of interest because it allegedly "confused" the "marginal efficiency of capital" (the net rate of return on an investment) with the rate of interest (Keynes 1936 [1997], 192-93), Rothbard points out that the "marginal efficiency of capital" is indeed the rate of interest. (ibid. 455) It is a price on the time market. The equilibrium rate of interest, or the rate of interest as it would tend to be in the evenly rotating economy, is determined solely by the time preferences of the individuals in society, and by no other factor. (ibid. 331-2)

\section{4. g.3. The important role of institutions}

Both post-Keynesians and Austrians tend to stress the role of institutions, in particular the role of bank and financial institutions, in economic processes.

Minsky highlights the significance of banks and financial institutions as profitseeking agents which react to perceived profit opportunities with financial innovations (and, so, stresses the endogeneity of the "effective" quantity of money and of the rate of interest). (Bellofiore and Ferri 2001, 21) 
From the beginning, Minsky extended profit-seeking behavior from entrepreneurs and businessmen to bankers and financiers. Later on, Minsky tried to introduce more heterogeneity of behaviour within the same class of agent, according to their financial position (hedge, speculative and Ponzi finance). (ibid. 23)

Minsky began his academic life as an analytical institutionalist and this thread would run throughout his entire work. (Merhling ibid. 149)

Part 4 of Minsky's Stabilizing an Unstable Economy is entitled Institutional Dynamics and contains a chapter entitled Banking in a Capitalist Economy. According to Minsky, his own view of money, banking, and financial markets consistent with the investment-financing perspective he presents, clearly differs radically from the standard view, which divorces how money affects the economy from any consideration of the specific transactions by which money is created. Both the monetarist and standard Keynesian approaches inappropriately assume that money can be identified quite independently of institutional usages.

On the Austrian side, Horwitz contends that "(w)hat the textbook model of the Classical economists misses is how money and the banking system work to ensure the valid insight behind Say's Law (...)" $(2000,86)$ and that "Austrian analyses of competition as a discovery process, the Hayekian emphasis on prices and knowledge, and the focus on the central role played by institutions, have all affected the way economists outside the Austrian tradition are doing their work." (ibid. 237)

The similarity does not go much further than that, however. First, there is complete disagreement as to the type or kind of institutions that would actually eliminate or at least mitigate the business cycle and macroeconomic instability. Whereas Austrians have made a case in favor of complete freedom of choice in 
currency and of a system of free banking, and thus the abolition of central banks, Minsky has argued in favor of Big Bank and Big Government.

Moreover post-Keynesians and Austrians conceptualize in entirely different ways the relationship between institutions and expectations and also the relationship between institutions and "the state of confidence" and fluctuations therein.

As pointed out already, a characteristic feature of Keynes's analysis is the uncertainty of the future. He suggests that in abnormal times in particular the economy will be driven up and down by baseless sentiments and waves of investor sentiment. Minsky agrees.

Austrians point out, however, that Keynesian policies, and in particular the interventions of Big Players, tend to create and enhance the irregular ups and downs that Keynes attributed to modern capitalism as such. In this sense, Keynesian policies tend to create a Keynesian economy.

Roger Koppl thus concludes:

“Those post-Keynesians who argue for discretionary state intervention as a result of certain features of economic behavior argue for policies that will increase-rather than reduce - the very behaviours they see as the problem." (ibid. 104)

This is further explained by the theory of Big Players (Koppl 2002) which is akin to the theory of regime uncertainty. (Higgs 1997)

Big Players and regime uncertainty_or uncertainty about the rules of the game-both artificially reduce the state of confidence by corrupting the expectations of financial intermediaries and businesses in the real economy. As long as the Big Player influence and regime uncertainty persist confidence will be low; the costs of financial intermediation will be high and the flow of credit 
will be low. Big Players and regime uncertainty have the potential to create a permanent slump. The low state of confidence they create is not self-correcting. In the next section I will consider in somewhat more detail the so-called Big Player theory.

\section{4. g.4. Uncertainty and the institutional context}

Both Minsky—and post-Keynesians more generally—on the one hand and Austrians on the other acknowledge the role and importance of Knightian uncertainty; as I will argue in this section, however, they disagree about the origins of (changes in) uncertainty and about how uncertainty relates to the relevant institutional context.

Certainly it is possible to distinguish degrees of uncertainty and to enquire what causes uncertainty to increase (or decrease). Moreover degrees of uncertainty can be related to the institutional context.

In one sense uncertainty is a universal aspect of human action in the sense that it is essentially inherent in action itself. (Mises ibid. 105) It cannot be excluded, however, that part of the uncertainties actors in the economy have to face do not have this universal character but can be related to the particular institutional context that is in place. These uncertainties are then contingent in the sense that they could conceivably be removed through institutional reform.

Considerations of this sort seem to underlie Keynes well-known proposal for "a somewhat comprehensive socialization of investment". (Keynes ibid. 378) According to Keynes, there are serious reasons to doubt that counter-cyclical policies narrowly conceived can save the market economy. Its flaws are too deeply rooted for that. The decentralized decision making, which is the heart and 
soul of the market economy, must be eliminated or at least severely restricted. Full employment would become possible only through centralization. (also Garrison ibid. 180 ff.)

As R. Garrison clarifies: “ (...) in addition to the irreducible uncertainty about the future "state of nature," each businessperson has to cope with the uncertainty about what other businesspeople will do. And in a capitalist setting each businessperson is driven by considerations of private costs and benefits rather than social costs and benefits. By itself, this added layer of uncertainty restricts the economy to a level of performance that Keynes finds wanting." (ibid. 180) Arguably, then, the central message of the General Theory derives from comparative institutions analysis and not from the analysis of cyclical fluctuations. (ibid. 185)

At the end of John Maynard Keynes (Minsky 2008) Minsky concludes as follows:

"Keynes believed that the policy implications of his theory were profound; not only did the theory point to ways in which a closer approximation to full employment can be sustained, but he envisaged that continuing full employment combined with an emphasis on consumption and public goods would lead to an egalitarian change in income distribution. The rentier income of the capitalist would disappear and the upper tail of the income distribution would be snipped off by taxation. He believed that both measures to raise the consumption function and the socialization of investment were necessary to sustain full employment and were desirable as social goals." (ibid. 157)

Austrians have acknowledged the link between institutional context and the nature of expectations but their conclusions are virtually opposite to those of the post-Keynesians. According to the theory of Big Players, a stable economic environment with atomistic competition tends to produce rational outcomes and 
prescient expectations. Lack of stability or atomism produces ignorance and uncertainty. In the presence of Big Players economic expectations tend to become less reliable. (Koppl 2002)

The central result of the theory of Big Players is that expectations depend on institutions. Expectations will be more prescient in some institutional environments than in others. Stable environments tend to produce prescient expectations. Instability reduces the reliability of economic expectations. It is also a statement about learning in the market process. Expectations depend on institutions because institutions influence the process by which individual knowledge is changed. (Koppl 2002, 96)

Adopting a Hayekian evolutionary stance, Butos and Koppl (1993) draw our attention to the filtering conditions of stability and atomicity. The failure of either condition creates a loose "system constraint" and thus a loose link between environment and expectations. The theory of "Big Players" gives an example of the empirical consequences of such a failure.

A Big Player has three defining characteristics. The player is big in the sense that its actions influence the market under study; it is insensitive to the discipline of profit and loss; and it is arbitrary in the sense that its actions are based on discretion rather than any set of rules. (Koppl 2014, 97)

If the market includes actors who are more or less immune from the competitive pressures of profit and loss, then the natural selection of rules will be inoperative with regard to these actors and the system constraint facing them will be loose. In such cases the privileged actors are free to act idiosyncratically. (Butos and Koppl ibid. 321)

If the rules of the road, "constitutional rules" in Buchanan's sense, change too often and by too much, then the general economic environment within which groups of rules compete will lack the stability necessary to select rules that 
induce actions consistent with underlying scarcities. (ibid. 320) Without such stability, reliable expectations about the consequences of our actions cannot be formed. (ibid. 321)

An activist central bank is a representative Big Player-it can be large, it is protected and its actions will be unpredictable. Minsky is the advocate par excellence of an eminent role for Big Players in the economy. (also Prychitko 2010)

These results also seem compatible with long-established conclusions of the socalled Socialist Calculation Debate. In the domain of money and banking Austrians have generally advocated the abolition of central banks and a move towards free (or decentralized) banking, despite some ongoing debates about how exactly free banking is to be defined. (See further.)

\section{4. (h) Explaining the upper turning point}

As pointed out previously, both Minsky's theory and the Austrian theory are theories of the upper turning point. Explaining the upper turning point of the business cycle requires putting together the various pieces of the puzzle. As we have seen, however, the explanatory elements in both approaches differ.

As Austrians see it, a particular integration of Austrian capital theory with monetary theory provides an explanation of why a credit-driven or policyinduced boom must turn into a bust. In other words the Austrian theory explains the inevitability of the upper turning point following a boom resulting from credit creation not backed by an increase in genuine saving.

How is the inevitability of the upper turning point explained in Minsky's theory? 
A crisis can occur if finance costs rise, if liquidity preference rises, or if income flows turn out to be less than expected. Endogenous processes tend to ensure that one of these (or all three) will, in fact, occur. (Wray 1992, 167-8)

Let's consider these elements in turn:

(a) Income flows turn out to be less than expected. Let's recall some fundamentals. In Minsky's analysis, investment spending is a fundamental determinant of aggregate effective demand, while investment is substantially determined by expected future aggregate demand. As Minsky puts it, investment this period is only forthcoming if investment is expected to take place next period since future investment will determine future aggregate demand and, thus, the aggregate profits which are necessary to validate investment projects undertaken this period. Each firm must weigh the supply price of capital against its demand price. The supply price will be a function of current production costs plus finance costs, including "lender's risk" if the project requires external finance. The demand price will be a function of the expected stream of returns to be generated over the life of the asset, taking into account also "borrower's risk". (Wray ibid. 167)

Expectations of increasing current output prices cause capital asset prices to rise relative to currently prevailing output prices. This, then, leads to an increase in borrowing to fund new investment.

The increased borrowing leads to higher interest payments which can only be met if expectations of increased future returns are confirmed. Bankers must share the expectations of the firms if new lending is to be extended. The increased lending is reflected in the firms' liabilities held as assets by the banking system to support its own liabilities, and acquired to fund the lending. The value of these liabilities also depends on the realization of expectations of future profit flows. A sufficiently large fall in capital asset prices may then have 
an impact on the value of bank liabilities. Uncertainty over the value of a bank's liabilities, i.e., its ability to meet its payment commitments, is the source of financial panic and crisis. For Minsky, Big Government spending can partially offset the fall in profit flows which results from a fall-off in investment or overoptimistic expectations, and in this way, provides support for consumption goods prices. (Kregel 1992, 87-8)

At this point the Austrian theory of the business cycle can claim to be more precise and more complete since it provides an explanation both of why overoptimistic expectations would arise in the first place and of why these expectations must necessarily reveal themselves as erroneous.

The Austrians would not dispute that a sudden and violent change in risk aversion- $\mathrm{or}$ in perceptions of the riskiness inherent in investment undertakings - is likely to cause the economy to plunge into recession. What they would dispute is that such changes in risk aversion or in perceptions tend to happen spontaneously. They are much more likely to occur during a period in which the counter-movements of a boom-bust cycle have already begun to make themselves felt. (Garrison 2001, 159-60)

(b) Liquidity preference rises.

In the vision of Minsky, liquidity preference is clearly of central importance for the explanation of financial instability. Liquidity preference is defined as a rational person's demand for money as an asset; this leads to a determinate demand function for money for any value of higher-order uncertainty. Any increase in uncertainty shifts the liquidity preference function, and this shift can be quite marked and sudden. (Minsky 1982, 131)

In addition to periods when the likelihood of various states of nature appears stable, there are troubled periods when the subjective estimates as to the likelihood of various states of nature are held with much less confidence. The 
risk-averter reaction to a decline in confidence is to attempt to increase the weight of assets that yield flexibility in portfolio choices, in other words, to increase the value not only of money but also of all assets that have broad, deep, and resilient markets.

Minsky assumes that two types of period can be distinguished: one in which beliefs are held with confidence concerning the likelihood of alternative states of nature occurring within some horizon period and the second in which such beliefs are most insecure. During these second periods-when what can be called higher-order uncertainty rules-markedly lower relative values are attached to assets whose nominal value depends upon the economy's performance. Periods of higher-order uncertainty will see portfolios shift toward assets that offer protection against large declines in nominal values. Even though flexibility is almost always a virtue, the premium on assets that permit flexibility will be larger in such periods of higher-order uncertainty.

An immediate effect of a change in liquidity preference is upon the money price of capital assets. A decrease in liquidity preference leads to an increase in the money price of capital assets. An increase in liquidity preference, which typically occurs when quasi-rents fail to validate debt structures or financial markets fail to refinance positions, will force attempts to reduce near-term payment commitments relative to expected quasi-rents. This will lead to a fall in the money price of capital assets. (ibid. 74-5)

As the implicit yield on money is primarily the value of the implied insurance policy it embodies, a decrease in uncertainty lowers this implicit yield and thus lowers the amount desired in portfolios. As all money must be held, as bankers are eager to increase its supply, and as its nominal value cannot decline, the money value of other assets, in particular real assets, must increase. (ibid. 133) 
Minsky emphasizes the fact that in the General Theory and in later pieces clarifying it, Keynes treated liquidity preference as a relation between money and the price level of capital assets, and that this perspective is thus to be distinguished from the monetarist money-interest rate relation in which the liquidity preference function becomes a demand function for money. (ibid. 78)

In Minsky's construction liquidity preference is clearly intended to play a role in explaining the upper turning point.

Just as supply prices tend to increase over the course of an expansion, demand prices will eventually fall. In an expansion, rising investment and appreciating asset prices generate aggregate profits, which tend to encourage both borrowers and lenders to accept liability structures in which payment commitments become closely articulated to receipts from assets. In fact, however, in the general euphoria debt commitments increase faster that the ability to pay. If a few large agents have second thoughts about their leverage ratios, or if a few expectations are disappointed, expected profits are reevaluated downward, and liquidity preference is increased. This process then reduces the demand price of capital assets below the supply price, so that investment falls. However, falling investment reduces aggregate profit flows so that profit expectations continue to fall and liquidity preference rises. This might cause a run to liquidity: firms that cannot meet payment commitments out of income flows or through borrowing must liquidate assets. However, asset liquidation under these circumstances requires devaluation and capital losses. As assets are devalued, ad as falling investment reduces profit flows, debts eventually are repudiated. Debt repudiation will reduce leverage ratios and the depression eventually sets the stage for the next expansion because interest rates will come down after balance sheets are liquidated through default. Furthermore, supply prices will tend to fall as rising unemployment reduces labor costs. (Wray ibid. 168) 
(c) Finance costs rise.

As an expansion proceeds, falling unemployment will tend to raise wages and cause capital asset supply prices to rise. Minsky argues that as bank balance sheets expand, there is upward pressure on interest rates because banks are concerned with leverage ratios. Furthermore, the central bank often attempts to constrain the growth of reserves at the peak of an expansion, which reduces bank liquidity (the ratio of cash assets to liabilities) and also tends to raise interest rates. Rising interest rates increase the portion of income flows which firms must commit to debt payments (firms must roll over some of the debt since construction projects take real time). As interest rates rise, "present value reversals" occur, which reduce planned investment, and may even cause some projects to be abandoned. Thus, current output prices and lender's risk tend to rise during an expansion, setting the stage for crisis by inhibiting investment. (also Wray ibid. 168)

Austrians would generally agree with the proposition that interest rates will tend to behave pro-cyclically in the later phases of an expansion. (Hayek 1969 [1978])

Moreover capital-based macroeconomics allows for deeper insight into this phenomenon and added explanatory power. The high real interest rates on the eve of the bust can be linked to "distress borrowing" and to "commitments" made by the business community during the preceding monetary expansion. (Garrison ibid. 73)

The unusually high (real) interest rates on the eve of the bust are accounted for in capital-based macroeconomics in terms of Hayek's (1937 [1939]) "Investment that Raises the Demand for Capital." The "investment" in the title of this article refers to the allocation of resources to the early stages of production; the "demand for capital" (and hence the demand for loanable funds) 
refers to complementary resources needed in the later stages of production. (also Garrison ibid. 73)

The question remains how strong the explanatory power or strength of Minsky's theory really is. This matter is much contested.

In their recently published book "The Rise and Fall of Money Manager Capitalism" Tymoigne and Wray $(2014,105)$ conclude:

"The Minskian framework does not merely help to explain the Great Recession; it helps to explain macroeconomic dynamics over the past century. It can explain why Finance Capitalism was unstable, why Managerial Capitalism was more stable, and how financial instability returned from the late 1960s. At the core of the explanation of the stability of Managerial Capitalism is the big government and big bank that emerged as a response to the Great Depression.”

In his recent assessment entitled "From Crisis to Confidence-Macroeconomics after the Crash" Austrian economist Prof. R. Koppl arrives at an entirely different conclusion, however, which is worth being quoted in full:

"It is hard to see how Minsky's theory goes beyond the claim that financial crises happen and that it is capitalism's fault. It is a theory of the state of confidence that consists principally in the proposition that, in an economy where businesses are free to source their capital from financial markets, if confidence starts out strong, it will grow to dangerous heights and then collapse. The theory tells us nothing about the conditions that encourage or discourage 'Ponzi Finance' except to say that overconfidence will sooner or later overtake the capitalists. Nor does it say anything about how rapidly the system will move from hedge finance to Ponzi finance. As with some versions of animal spirits we have investor confidence moving up and down for no particular reason in an irregular and unpredictable way. It is hard to see how this theory goes beyond the claim that financial crises do sometimes happen, which is hardly an 
explanation of why they happen. The human psychology behind the theory seems thin." (Koppl 2014, 66-7)

Koppl's critique amounts to the claim that the theory is largely descriptive and lacks explanatory strength.

\section{4. (i) The role of innovation}

According to economists working in the tradition of Minsky, financial innovation is to be considered an important economic factor that promotes instability. Financial innovations end up promoting instability in two ways. Over a period of enduring expansion, innovation involves extending the use of existing financial products to more risky projects and the creation of financial products with higher embedded leverage (leverage on leverage). In addition, new financial products are marketed as sophisticated products that are better able to measure and/or to protect against risks associated with leverage, which tends to let people believe that the use of debt is safer than in the past. All this was observed very clearly over the past thirty years especially with the growth of securitization and derivative markets, and the belief that risk was better spread around in the system and allocated toward entities that could bear it best. (Tymoigne and Wray ibid. 33)

Indeed in the wake of the financial crisis it has been possible to observe a tendency to demonize structured finance and to consider its use as a scapegoat and as the culprit of problems in the financial markets. However, it is difficult to see what the principled argument against the use of structured finance is. Structured finance is merely a tool. It can make credit cheaper by allocating it more efficiently. Rather it is the incentives that encouraged banks to move risk to insurance companies, $\mathrm{ABCP}$ investors, and other investors that caused the 
problems. Thus while structured finance itself is not bad, it was certainly possible to use it badly. (Murphy 2009, 221)

\section{4. (j) Interpreting Recent Historical Evidence: Minsky, the Austrians, and the Financial Crisis --}

The Financial Crisis and the Great Recession have offered various opportunities to heterodox schools in economics to try to demonstrate the fertility of their respective approaches and to claim the superiority of these vis-à-vis mainstream conceptualizations. Post-Keynesians as well as Austrians have actively participated in these debates. Several collections of papers have been published. Reference can be made to, among others, Kates (2010 and 2011), Dejuán et al. (2011) and some of the papers in Page West III and Whaples (2013). Mention should also be made of Booth (2009), Friedman (2011) and Beckworth (2012). Howden (2011) offers a European perspective.

The final report of the Financial Crisis Inquiry Commission (FCIC) makes a strong case that the global financial crisis was foreseeable and avoidable. It did not "just happen"; it had nothing to do with "black swans with fat tails"; it was not an extreme event that "Nature" drew randomly from a set of possible outcomes. According to the FCIC report, the global financial crisis represents a dramatic failure of corporate governance and risk management, in large part a result of an unwarranted and unwise focus by financial institutions on trading (actually, gambling) and rapid growth. (FCIC 2011)

Tymoigne and Wray (ibid. 250) note that, in all this, the biggest banks were aided and abetted by government "regulators" and "supervisors" who not only failed to properly oversee these institutions, but, indeed, continually pushed for 
deregulation and desupervision in favor of "self-regulation" and "selfsupervision."

There is clearly some danger, however, in focusing on "bad actors", bad financial practices, and "bad events". It is important to understand longer-term trends.

As noted already, Tymoigne and Wray (2014) argue that Minsky's framework helps us to understand what has happened over the past half century instead of merely explaining the recent boom and crisis.

The view taken in their book deviates somewhat from the FCIC report's conclusions: financial fragility had grown on trend, making "it" (in the words of Minsky, referring to a Fisher's type debt-deflation) likely to "happen again"even without "bad" behaviors by institutions and their regulators. They attempt to understand the "Minskyan" transformation—so that while the global financial crisis was not strictly inevitable, the financial structure made a crisis highly probable.

They explain how capitalism in developed countries progressively moved from a more stable form of capitalism that Minsky called Managerial Capitalism to a more unstable form called Money Manager Capitalism. The 1980s S\&L crisis put the final nail in the coffin of Managerial Capitalism as the system moved to Money Manager Capitalism (MMC). MMC is characterized by the rise of a predatory state, the disengagement of the government, the return of a pro-market mentality, and a growing role of financial markets in determining economic outcomes.

Two main factors contributed to the Great Recession: pro-market policies and the decline in underwriting standards on loans and securities. Both contributed to the growth of indebtedness in the private sector and to the change in the quality of this indebtedness for the worse. This change in quality manifested 
itself primarily through a move toward collateral-based lending, i.e., lending based on growing asset prices instead of income. The Great Recession was not a liquidity crisis but rather a solvency crisis. Unfortunately, most policies that have been implemented in the aftermath were aimed at solving the liquidity crises that occurred after the fall of Lehman Brothers. Nothing substantial has been done to address the underlying solvency problems. Instead of hiding losses and supporting poor management, the government should promote an orderly liquidation of banks. These authors conclude that the two main lessons we should have learned (but probably did not) from the global financial crisis is that the Great Recession did not happen by accident and that the global financial crisis was not a "liquidity crisis".

While Austrians might agree with certain descriptive elements contained in this narrative, they would certainly sharply dispute the thesis that the Great Recession was a consequence of pro-market policies.

Indeed the Austrians, in general agreement with their pro-free-market philosophy, have in particular emphasized and highlighted (1) the role of the Fed in engineering excessive money and credit creation and (2) the perverse incentive effects of disastrous regulations.

(a) The role of the Fed

John Taylor (of the "Taylor rule") has explained how, beginning in late 2001, the Federal Reserve, under the chairmanship of Alan Greenspan, began pushing the federal funds rate down, eventually to a level at which it was actually negative. (Taylor 2009; 2011) The result was that for several years the federal 
funds rate was far below the optimal level prescribed by the Taylor rule, which calculates that level on the basis of inflation and output.

Accordingly Austrians have generally considered that the subprime crisis constitutes a paradigm case of applicability of their theory. (Fillieule 2010, 17980)

Thus Jesús Huerta de Soto (2011) has claimed that the approach of the Austrian School to the study of business cycles is well equipped to explain recent events. This author reminds that according to the Austrian view there is no way in which the economy can escape the sacrifice of present consumption and bypass the discipline of accumulated saving. Credit expansion and (fiduciary) inflation of the media of exchange offer no short cut to stable and sustained economic development. Money that does not originate from saving, but is generated only from credit expansion is bound to be channeled into "bad" investments, which eventually result in a reduction of capacity and employment, produce inflation in goods and assets markets, and give rise to speculative bubbles that will burst sooner or later. Huerta de Soto proposes a fundamental reform of financial and monetary institutions. (See further.)

Gjerstad and Smith (2014) do not explicitly refer to the Austrian theory of the business cycle but several of their findings seem to be compatible with an interpretation in such terms.

Experimental research informs the study of recessions and vice versa, greatly enhancing our understanding of the incentive and performance characteristic of markets and demonstrating the key proposition that not all markets are created equal. There are two fundamental types of markets, the performance of which has been studied in the laboratory. The first type is supply-and-demand markets that are repeated as flows of goods or services during successive time periods. These markets tend to converge quickly. 
The second type is asset-market experiments. Smith et al. (1988) showed that human behavior in asset -trading markets leads to dramatically different convergence results than those in commodity-flow markets, even under conditions of high transparency. Subsequent experimental research on asset market bubbles has confirmed that asset prices typically deviate substantially from those predicted by the rational expectations market model. (ibid. 43)

People in laboratory asset-market experiments, as well as their "sophisticated" counterparts in economies today, become entangled in self-sustaining expectations of escalating prices. One of the important parallels in behavior between experimental price bubbles and those in the housing market is that, as in the laboratory, money matters: the availability and aggressive marketing of mortgage credit supported the housing bubble until credit started to be withdrawn. (ibid. 269-70) The observation that prices can be sustained longer and more vigorously if momentum investors have more liquidity is consistent with experimental findings. More money makes for bigger bubbles. A significant and sustained change in monetary policy beginning in 2001 is potentially implicated in strengthening and imparting longer life to the mortgage market growth that fueled the housing price bubble. (ibid. 166-7)

(b) The Regulatory Failure Thesis

Friedman and Kraus (2011) debunk various elements of the conventional wisdom about what caused the financial crisis and argue that the crisis was a regulatory failure in which the prime culprit was the set of regulations governing banks' capital levels known as the Basel rules. Theirs is an "incentives story" but it is not a moral-hazard story. They stress the role of radical ignorance on all sides. The triple-A ratings on MBS were conferred by three bond-rating 
corporations that had been protected from competition by Securities and Exchange Commission regulation dating back to 1975 . Not only bankers but investors of all kinds were either unaware that these three corporations were protected, or they were unaware of the implications of this protection for the accuracy of their ratings. This lack of awareness was apparently shared by the banking regulators, who had incorporated the three companies' ratings into the Recourse Rule and Basel II. The financial crisis was transmitted into the nonfinancial or "real" economy through a lending contraction that began in mid2007, as banks were required to "mark to market" their holdings of mortgagebacked securities in line with market fears about the value of these securities, due to rising rates of subprime mortgage delinquencies.

As an aside, the fundamental question can here be raised of why the opinions and conclusions of historians diverge so strongly and widely? What is the philosophical nature of these disagreements between historians?

One possible answer is that the disagreement is to be sought and found in the domain of theory. Interpretations of historical facts differ because the underlying theories differ.

As Ludwig von Mises wrote:

"Only those who believe that facts write their own story into the tabula rasa of the human mind blame the historians for such differences of opinion. They fail to realize that history can never be studied without presuppositions, and that dissension with regard to the presuppositions, i.e., the whole content of the nonhistorical branches of knowledge, must determine the establishment of historical facts." $(1949,53)$

This fact justifies the attention which has been devoted in this paper to a comparison of the respective theoretical presuppositions. It equally legitimizes, 
to some degree, purely theoretical research within economics, i.e., the study of economics from a purely theoretical perspective.

At a still deeper (or higher) level the disagreement is of an epistemological, methodological and thus philosophical nature.

At the epistemological level Mises was strongly convinced of the objective and universalistic character of economic theory (praxeology). He rejected various forms of empiricism, historicism and relativism. His methodological views are not shared universally within the economics profession, however.

Thus two leading followers of Minsky wrote recently:

"Minsky was highly influenced by Institutional Economics and believed that an economic theory must be rooted into the institutional structure of the economic system it tries to explain. He rejected the idea that an economic theory can apply to all economic systems past and present, and argued that a careful analysis of the existing socio-political-economic institutions is necessary to formulate a meaningful analysis of existing economic problems." (Tymoigne and Wray ibid. 7)

Austrians intent upon convincing their scientific and ideological opponents may consider such statements as an encouragement to go on clarifying and defending their meta-theoretical and methodological presuppositions.

\section{4.(k) Policy Implications}

Minsky's theory of money supply endogeneity leads clearly to the conclusion that monetary growth policies are not effective at controlling financial market forces and are particularly inefficient in controlling the thrust toward speculative 
finance. At the same time, Minsky also argues that two other policy instruments (federal government deficit spending and lender-of-last-resort interventions by the Federal Reserve) are extremely effective, if not at achieving full employment, at least in limiting the downside variability of incomes and liquidity during economic downturns, particularly in periods of incipient financial crisis. Drawing from Kalecki's well-known accounting identity that, in a closed economy, profits equal investment plus the government deficit, Minsky argues that the effect of deficit spending during a downturn is to establish a floor for profits. At the same time, lender-of-mast-resort interventions are able to counteract the liquidity shortages of distressed financial firms. Because of the powerful effects of these policies, Minsky believed firmly that another largescale debt deflation and depression, such as occurred in the 1930s, could, at least in principle, be prevented from happening again.

It is important to see that in Minsky's "two price" view of the world, two stabilizers are needed: Big Government (BG) and a Big Bank (BB). For Minsky, Big Government spending can partially offset the fall in profit flows which results from a fall-off in investment or overoptimistic expectations, and in this way, provides support for consumption goods prices. But it cannot directly support the fall in the value of a bank's assets which results from a fall in capital goods prices. This is why Big Government, by itself, is not enough to counter instability. A Big Bank must come in to stabilize the prices of capital assets.

In the Minskyan scenario, deficit spending and lender-of-last-resort interventions, and the potential costs associated with risky financial practices are, to a considerable extent, socialized since government rather than firms absorbs these costs. The socialization of financial market risk promotes fragility since, as Minsky acknowledges, once borrowers and lenders recognize that the downside instability of profits has decreased, there will be an increase in the willingness and ability of business and bankers to debt finance. If the cash flows 
to validate debt are virtually guaranteed by the profit implications of big government, then debt-financing of positions in capital assets is encouraged. (Minsky 1986)

Austrians to the contrary generally deplore the movement towards command and control which they believe is a mistake that threatens the wealth and welfare of the people. Instead we need to restore the rule of law and economic liberalism. In other words, in order to significantly reduce regime uncertainty and Big Player influence we need to take the "constitutional turn", which may be considered both a Hayekian move and a public choice move. Such a economic constitution would have to comprise: (a) Fiscal discipline since when government revenues are big enough, uncertainty over the tax bill becomes destructive regime uncertainty and a drag on output; (b) A monetary constitution since only if current austerity is combined with sensible reforms to create a sound monetary constitution will the likelihood of future debt crises be reduced; (c) A regulatory constitution since without real regulatory reform there is little hope to escape crony capitalism that increases the role of Big Players; we should regulate the regulators in the same way that markets regulate private firms. (Koppl 2014)

Let's consider in somewhat more detail the monetary dimension.

In the context of a central banking regime, Selgin (1997) has advocated a socalled productivity norm as the alternative to zero (or positive) inflation.

Under a productivity norm, changes in velocity would be prevented (as under zero inflation) from influencing the price level through offsetting adjustments in the supply of money. But adverse "supply shocks" like wars and harvest failures would be allowed to manifest themselves in higher output prices, while permanent improvements in productivity would be allowed to lower prices permanently. (ibid. 10) In reality productivity is constantly changing, generally 
for the better. In the real world, a little secular deflation, along with upward movements in the price level mirroring adverse supply shocks, would be better than zero inflation. (ibid. 14)

Huerta de Soto $(2012,736)$ argues that in order to establish a truly stable financial and monetary system for the twenty-first century, a system which protects our economies as far as possible from crisis and recessions, the following will be necessary: (1) complete freedom of choice in currency; (2) a system of free banking, and the abolition of the central bank; and most importantly, (3) obligatory observance of traditional legal rules and principles by all agents involved in the free banking system, particularly the important principle according to which no one may enjoy the privilege of loaning something entrusted to him on demand deposit. In short it is necessary to maintain at all times a banking system which includes a 100-percent reserve requirement.

Huerta de Soto's definition of free banking is not shared, however, by authors who advocate a fractional- reserve free banking system as an alternative to central banking. (Selgin 1988) Although the proposal for fractional-reserve free banking is fraught with serious conceptual problems (Van den Hauwe 2009b), the debate between the two factions can be expected to go on.

\section{Conclusion: superficial similarities, profound divergences}

Minsky is difficult to categorize as an economist. While his status as a Keynesian seems somewhat questionable, the analogies and/or similarities of his theoretical analysis with the analysis of the Austrians are no more than superficial. There undeniably exists some scope for cross-fertilization between 
both approaches but at a fundamental conceptual level the theories are difficult to reconcile.

Much of the disagreement on policy issues between post-Keynesians and Austrians hinges on the answer to the underlying question of whether the actions and interventions of Big Players in mixed economies are stabilizing or destabilizing. Post-Keynesians believe they can indeed be stabilizing; Austrians to the contrary believe that mostly they will be destabilizing.

Minsky's policy conclusions manifest a lack of familiarity with the conclusions of the Austrian analysis of the problems of central planning as well as a blind faith in the stabilizing role that can be played by Big Players such as Big Bank and Big Government.

The Austro-Wicksellian paradigm arguably provides superior insights that can complement and correct Minskyan analyses of the historical experience of the Financial Crisis and Great Recession.

\section{Ludwig van den Hauwe}

\section{References}

Beckworth, D. (2012), Boom and Bust Banking-The Causes and Cures of the Great Recession, Oakland: The Independent Institute.

Bellofiore, R. and Piero Ferri (2001a), Financial Keynesianism and Market Instability-The Economic Legacy of Hyman Minsky Volume I, Cheltenham: Edward Elgar.

Bellofiore, R and Piero Ferri (2001a), Introduction: 'Things fall apart, the centre cannot hold', in: Bellofiore and Ferri (2001a), 1-29 and in: Bellofiore and Ferri (2001b), 1-29. 
Bellofiore, R. and Piero Ferri (2001b), Financial Fragility and Investment in the Capitalist Economy-T he Economic Legacy of Hyman Minsky Volume II, Cheltenham: Edward Elgar.

Butos, W.N. and R. Koppl (1993), Hayekian Expectations: Theory and Empirical Expectations, Constitutional Political Economy, Vol. 4 N 3, 303-29.

Cantillon, R. ([1755] 2001), Essay on the Nature of Commerce in General, London: Transaction Publishers.

Cochran, J.P. and F.R. Glahe (1992), The Use and Abuse of Equilibrium in Business Cycle Theory-A Praxeological Approach, Cultural Dynamics, 5: 35670

Cochran, J.P. and F.R. Glahe (1999), The Hayek-Keynes Debate-Lessons for Current Business Cycle Research, Lewiston: The Edwin Mellen Press.

De Antoni, E. (2010), Minsly's 'financial instability hypothesis': the not-tooKeynesian optimism of a financial Cassandra, in: Zambelli (2010), 462-84.

Dejuán, Ó, Febrero E. and Marcuzzo, M.C. (2011), The First Great Recession of the $21^{\text {st }}$ Century, Cheltenham: Edward Elgar.

Fazzari, S. and Dimitri B. Papadimitriou (eds.) (1992), Financial Conditions and Macroeconomic Performance, New York: Sharpe.

Fazzari, S. (1992), Introduction: Conversations with Hyman Minsky, in Fazzari and Papadimitriou (1992), 3-26.

Fillieule, R. (2010), L'école autrichienne d'économie-Une autre hétérodoxie, France: Septentrion.

Financial Crisis Inquiry Report (2011), New York: PublicAffairs. 
Friedman J. (ed.) (2011), What Caused the Financial Crisis?, Oxford: University of Pennsylvania Press.

Friedman, J. and Wladimir Kraus, (2011), Engineering the Financial CrisisSystemic Risk and the Failure of Regulation, Philadelphia: University of Pennsylvania Press.

Garrison, R.W. (1992), Is Milton Friedman a Keynesian? In: Skousen (1992), $131-47$.

Garrison, R.W. (2001), Time and Money-The Macroeconomics of Capital Structure, London: Routledge.

Garrison, R.W. (2005), The Austrian School, in: Snowdon B. and Vane H.R. (2005), 474-516.

Gjerstad, S.D. and V.L. Smith (2014), Rethinking Housing Bubbles-The Role of Household and Bank Balance Sheets in Modeling Economic Cycles, New York: Cambridge University Press.

Gloria-Palermo, S. (1999), The Evolution of Austrian Economics, London : Routledge.

Gloria-Palermo, S. (2013), L'école économique autrichienne, Paris: La Découverte.

Godley, W. and M. Lavoie (2012), Monetary Economics-An Integrated Approach to Credit, Money, Income, Production and Wealth, New York : Palgrave Macmillan.

Goodspeed, T.B. (2012), Rethinking the Keynesian Revolution, New York: Oxford University Press.

Hayek, F.A. (1978) New Studies in Philosophy, Politics, Economics and the History of Ideas, London: Routledge and Kegan Paul. 
Hayek, F.A. (1969 [1978]), Three Elucidations of the Ricardo Effect, in: Hayek (1978): 165-178.

Hayek, F.A. (1939) Profits, Interest and Investment, London: Routledge \& Kegan Paul.

Hayek, F.A. (1937 [1939], Investment that Raises the Demand for Capital, in: Hayek (1939) : 73- 82.

Higgs, R. (1997), Regime uncertainty: why the Great Depression lasted so long and why prosperity resumed after the war, Independent Review, Volume I $\mathrm{N}^{\circ} 4$ : 561-90.

Horwitz, S. (2000), Microfoundations and Macroeconomics-An Austrian Perspective, London: Routledge.

Howden, D. (2011), Institutions in Crisis-European Perspectives on the Recession, Cheltenham: Edward Elgar.

Huerta de Soto, J. (2011), A brief note on economic recessions, banking reform, and the future of capitalism, in: Dejuán et al. (2011): 33-41.

Huerta de Soto, J. (2012), Money, Bank Credit and Economic Cycles, Auburn : Ludwig von Mises Institute.

Ikeda, S. (1997), Dynamics of the Mixed Economy, London: Routledge.

Kates, S. (ed.) (2010), Macroeconomic Theory and its Failings, Cheltenham: Edward Elgar.

Kates, S. (ed.) (2011), The Global Financial Crisis-W hat Have We Learnt? Cheltenham: Edward Elgar.

Keynes, J.M. (1936 [1997]), The General Theory of Employment, Interest, and Money, New York: Prometheus Books. 
Knoop, T.A. (2008), Modern Financial Macroeconomics-Panics, Crashes, and Crises, Oxford: Blackwell Publishing.

Koppl, R. (2002), Big Players and the Economic Theory of Expectations, New York: Palgrave.

Koppl, R. (2014), From Crisis to Confidence-Macroeconomics after the Crash, London: IEA.

Kregel, J.A. (1992), Minsky's “Two rice” Theory of Financial Instability and Monetary Policy: Discounting versus Open Market Intervention, in: Fazzari and Papadimitriou (1992), 85-103.

Lachmann L. (1937 [1994]), Uncertainty and Liquidity-Preference, in Lavoie (1994), 29-41.

Lavoie, D. (ed.) (1994), Expectations and the Meaning of Institutions, London: Routledge.

Leijonhufvud, A. (1981), Information and Coordination-Essays in Macroeconomic Theory, New York: Oxford University Press.

Leijonhufvud, A. (1981), The Wicksell Connection: Variations on a Theme, in: Leijonhufvud (1981), 131-202.

Leijonhufvud A. (2009), Out of the corridor: Keynes and the crisis, Cambridge Journal of Economics, 33: 741-757.

Machlup, F. (1976), Hayek's Contribution to Economics, in: Machlup, ed., Essays on Hayek, Hillsdale, Mich.: Hillsdale College Press, 13-59.

Mehrling, P. (1999), The vision of Hyman P. Minsky, Journal of Economic Behavior \& Organization, 39: 129-58. 
Meltzer, A.H. (1988), Keynes's Monetary Theory_A Different Interpretation, New York: Cambridge University Press.

Menger, C. (1871[1994]), Principles of Economics, Grove City: Libertarian Press.

Minsky, H.P. (1975 [2008]), John Maynard Keynes, New York: McGraw Hill.

Minsky, H.P. (1982), Can "It" Happen Again—Essays on Instability and Finance, New York: Sharpe.

Minsky, H.P. (1986 [2008]), Stabilizing an Unstable Economy, New York: McGraw Hill.

Minsky, H.P. (1993), On the non-neutrality of money, FRBNY Quarterly Review (Spring), 77-82.

Minsky, H.P. (2004), Induced Investment and Business Cycles, Cheltenham: Edward Elgar.

Mises, L. von (1949 [1966]), Human Action—A Treatise on Economics, Fourth Revised Edition, New York: FEE.

Murphy, D. (2009), Unravelling the Credit Crunch, London: CRC Press.

O’Driscoll G. and Rizzo M.J. (1996), The Economics of Time and Ignorance, London: Routledge.

Page West III G. and Robert M. Whaples (eds.) (2013), The Economic Crisis in Retrospect—Explanations by Great Economists, Cheltenham: Edward Elgar.

Papadimitriou, D.B. (2004), Introduction in: Minsky (2004), ix-xvi.

Papadimitriou, D.B. and L. Randall Wray (2010), The Elgar Companion to Hyman Minsky, Cheltenham: Edward Elgar. 
Posner, R.A. (2011), The Causes of the Financial Crisis, in: Friedman (2011), 279-94.

Prychitko, D.L. (2010), Competing explanations of the Minsky moment: The financial instability hypothesis in light of Austrian theory, Review of Austrian Economics, 23: 199-221.

Rabin, A.A. (2004), Monetary Theory, Cheltenham: Edward Elgar.

Ravier, A.O. (2013), Dynamic Monetary Theory and the Phillips Curve with a Positive Slope, Quarterly Journal of Austrian economics, Vol. 16, № 2, 165-86.

Rothbard, M.N. (1962[2004]), Man, Economy, State, Auburn: Ludwig von Mises Institute.

Selgin G.A. (1988) The Theory of Free Banking-Money Supply under Competitive Note Issue, Rowman \& Littlefield.

Selgin, G. (1997), Less Than Zero-The Case for a Falling Price Level in a Growing Economy, London : IEA.

Simpson, D. (2013), The Rediscovery of Classical Economics, Cheltenham: Edward Elgar.

Skousen, M. (ed.) (1992) Dissent on Keynes-A Critical Appraisal of Keynesian Economics, New York: Praeger.

Smith, V.L. (1991), Papers in Experimental Economics, New York: Cambridge University Press.

Smith, V.L., Suchanek, G.L. and Williams, A.W. (1988), Bubbles, crashes, and endogenous expectations in experimental spot asset markets, in: Smith, V.L. (1991), 339-371. 
Smithin, J. (2013), Essays in the Fundamental Theory of Monetary Economics and Macroeconomics, Singapore: World Scientific.

Snowdon B. and Vane H.R. (2005), Modern Macroeconomics-Its Origins, Development and Current State, Cheltenham: Edward Elgar.

Svetlova E. and Fiedler M. (2011), Understanding crisis: on the meaning of uncertainty and probability, in Dejuán et al. (2001), 42-62.

Taylor, J.B. (2009), Getting Off Track-How Government Actions and Interventions Caused, Prolonged, and Worsened the Financial Crisis, Stanford: Hoover Institution Press.

Taylor, J.B. (2011), Monetary Policy, Economic Policy and the Financial Crisis: An Empirical Analysis of What Went Wrong, in: Friedman (2011), 150-171.

Tymoigne, E. and L. Randall Wray (2014), The Rise and Fall of Money Manager Capitalism, London: Routledge.

Van den Hauwe, L. (2009a), Foundations of Business Cycle Research Volume I, Saarbrücken: VDM Verlag.

Van den Hauwe, L. (2009b), Three Essays in Monetary Theory, Norderstedt: BoD.

Van den Hauwe, L. (2011), John Maynard Keynes and Ludwig von Mises on Probability, .Journal of Libertarian Studies 22, No. 1: 471-507.

Wicksell, K. (1936[1965]), Interest and Prices, New York: Augustus M. Kelley. Wolf, M. (2014), The Shifts and the Shocks, London: Allen Lane.

Wray, L.R. (1992), Minsky's Financial Instability Hypothesis and the Endogeneity of Money, in: Fazzari and Papadimitriou (1992), 161-180. 
Yeager, L. (1988), The Austrian School on Money and Gold, Journal of Economic Studies, 15(3/4), 92-105.

Zambelli, S. (ed.) (2010), Computable, Constructive and Behavioural Economic Dynamics, London: Routledge. 